\title{
Neuroprotective effects of novel compound Tozan on cognition, neurogenesis and apoptosis in diabetes
}

\author{
Su-Su Tang", Shu-Yun Xing", Xue-Jiao Zhang", Xiao-Qian Ren, Hao Hong, Yan Long \\ Department of Pharmacology, Key Laboratory of Neuropsychiatric Diseases, China Pharmaceutical University, Nanjing, China \\ Contributions: (I) Conception and design: SS Tang; (II) Administrative support: Y Long, H Hong; (III) Provision of study materials or patients: SS \\ Tang; (IV) Collection and assembly of data: XJ Zhang, XQ Ren; (V) Data analysis and interpretation: SY Xing; (VI) Manuscript writing: All authors; \\ (VII) Final approval of manuscript: All authors. \\ "These authors contributed equally to this work. \\ Correspondence to: Su-Su Tang; Yan Long. Department of Pharmacology, China Pharmaceutical University, Nanjing 210009, China. \\ Email: tang_susu@126.com; long7027610@163.com.
}

\begin{abstract}
Background: Cognitive impairment is a serious complication of diabetes that manifests as an impairment of spatial memory and learning ability. Its pathogenesis is unclear, and effective therapeutic drugs are very limited. Our group designed and synthesized a novel compound named 3-p-tolyl-9H-xanthen-9-one (Tozan). In this study, we sought to investigate the effects and mechanism of Tozan on diabetic cognitive impairment. Methods: Methylglyoxal (MG)-induced SH-SY5Y cells and streptozotocin (STZ)-induced type 1 diabetic mice were treated with Tozan. Methyl thiazolul tetrazolium (MTT) and lactate dehydrogenase (LDH) were used to test cytotoxicity. Morris water maze (MWM) and Y-maze tests were used to evaluate cognitive function. Immunofluorescence and western blot analyses were used to evaluate neurogenesis, apoptosis, and signal transduction pathway-related proteins. In addition, Lentivirus (LV)-estrogen receptor beta (ER $\beta)$ ribonucleic acid interference (RNAi) was used to knockdown the ER $\beta$ gene in SH-SY5Y cells.

Results: We found that Tozan ameliorated MG-induced cytotoxicity in SH-SY5Y cells, improved cognitive dysfunction in STZ-induced type 1 diabetic mice, increased neurogenesis, and prevented apoptotic responses in vitro and in vivo. Importantly, Tozan $(2,4$, and $8 \mathrm{mg} / \mathrm{kg})$ mediated phosphatidylinositol-3-kinase and protein kinase B cAMP-response element binding protein (PI3K/Akt-CREB) signaling by activating membrane ER $\beta$, and a high dose of Tozan $(8 \mathrm{mg} / \mathrm{kg})$ mediated CREB signaling by activating nuclear ER $\beta$ in the hippocampus. Notably, Tozan did not have an anti-apoptosis and regeneration protective role in ER $\beta$ gene knockdown cells.

Conclusions: Our study demonstrates Tozan's contributions to and role in cognition, neurogenesis, and apoptosis in diabetes, and lays an experimental foundation for the development of new anti-diabetic cognitive impairment drugs.
\end{abstract}

Keywords: Tozan; type 1 diabetes; estrogen receptor $\beta$ (ER $\beta)$; cognition; neurogenesis; apoptosis

Submitted Jul 26, 2021. Accepted for publication Sep 10, 2021.

doi: 10.21037/atm-21-4439

View this article at: https://dx.doi.org/10.21037/atm-21-4439

\section{Introduction}

Diabetes mellitus is a kind of metabolic disease characterized by hyperglycemia and caused by insulin secretion defects or insulin function disorders. The International Diabetes Federation estimated that there was a total of 415 million diabetics (aged 20-79 years) in 2015, and projected that there would be 642 million diabetics by 2040 (1). Diabetes causes a series of chronic complications, such as cardiovascular disease, diabetic nephropathy, foot ulcers, retinopathy, and nerve damage. There is increasing evidence that diabetes affects the central nervous system (2). The most common complications of diabetic brain include cognitive impairment and the development of dementia (3). The pathogenesis of cognitive impairment is unknown; however, it may be 
A

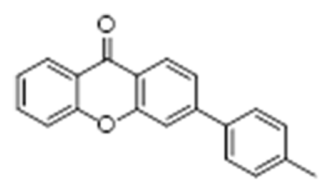

C

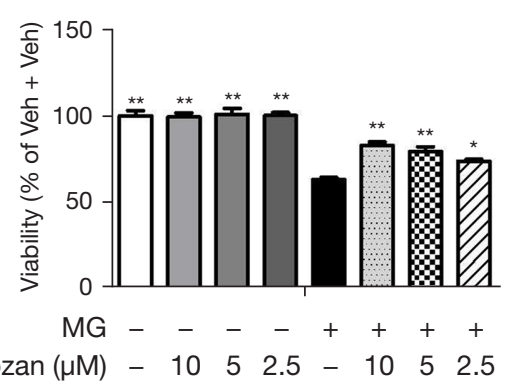

B
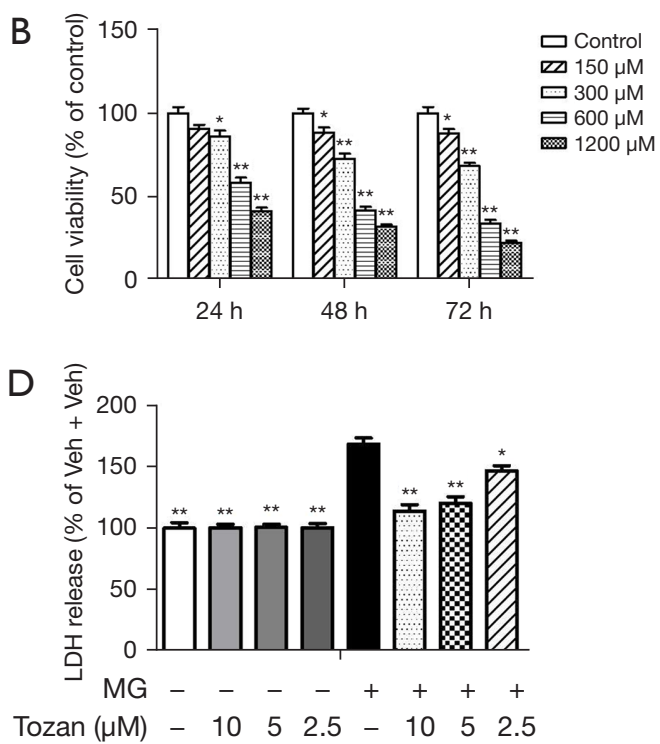

Figure 1 Tozan ameliorates cell damage caused by MG. (A) The structure of Tozan. The compound structure was confirmed by $1 \mathrm{H}$ NMR and 13C NMR, details as follows: M. P. $127-128^{\circ} \mathrm{C}$; $1 \mathrm{H} \mathrm{NMR} \mathrm{(500} \mathrm{MHz,} \mathrm{CDCl3)} \delta(\mathrm{ppm}) 8.35-8.32(\mathrm{~m}, 2 \mathrm{H}), 7.71-7.68(\mathrm{~m}, 1 \mathrm{H}), 7.63(\mathrm{~d}$, $\mathrm{J}=1.5 \mathrm{~Hz}, 1 \mathrm{H}), 7.58-7.55(\mathrm{~m}, 3 \mathrm{H}), 7.46(\mathrm{~d}, \mathrm{~J}=8.5 \mathrm{~Hz}, 1 \mathrm{H}), 7.36(\mathrm{t}, \mathrm{J}=7.5 \mathrm{~Hz}, 1 \mathrm{H}), 7.28(\mathrm{~d}, \mathrm{~J}=8.0 \mathrm{~Hz}, 2 \mathrm{H}), 2.40$ (s, 3H); $13 \mathrm{C} \mathrm{NMR}(125$ $\mathrm{MHz}, \mathrm{CDCl} 3) \delta$ (ppm) 176.9, 156.4, 156.2, 147.7, 138.8, 136.2, 134.6, 129.7, 127.4, 127.1, 126.6, 123.8, 122.7, 121.9, 120.3, 117.9, 115.4, 21.2. (B) Effect of MG on the survival rate of SH-SY5Y cells at different doses and different times. Cell viability was assessed by the MTT method. Results are shown as means $\pm \mathrm{SEM}(\mathrm{n}=6)$. ${ }^{*} \mathrm{P}<0.05,{ }^{* *} \mathrm{P}<0.01 v s$. control group. (C,D) Tozan increased the survival rate of $M G-$ induced cells as determined by the MTT method and decreased the LDH release of MG-induced SH-SY5Y cells. Data are shown as means $\pm \operatorname{SEM}(\mathrm{n}=6) .{ }^{*} \mathrm{P}<0.05,{ }^{*} \mathrm{P}<0.01$ vs. $\mathrm{MG}+$ Veh group. $\mathrm{MG}$, methylglyoxal; SEM, standard error of mean.

related to abnormal glucose metabolism, cerebrovascular neuropathy, and cell apoptosis. In several recent clinical and epidemiological studies, older women with diabetes and obesity showed a higher frequency of cognitive decline than men of the same age, and the risk of cognitive impairment was found to be closely related to the loss of sex steroid hormones (3-5).

Estrogen is the primary female sex hormone and plays an important role in the reproductive system. In recent years, studies have shown that estrogen also plays a neuroprotective role in neurodegenerative diseases and injuries through a variety of mechanisms, including by enhancing antioxidant activity, altering glutamate receptor activity, reducing immune inflammation, providing neurotrophic support, and enhancing synaptic development (6). Hormone replacement treatment is a therapy that provides natural hormones or replacement hormones to patients with insufficient hormone levels, mainly postmenopausal women. Estrogen replacement therapy (ERT) can improve cognitive impairment and reduce the risk of dementia; however, it also increases the risk of breast, ovarian, and endometrial cancers in women (7).
Estrogen non-specifically binds to estrogen receptor (ER) subtypes (i.e., $\mathrm{ER} \alpha$ and $\mathrm{ER} \beta$ ), and when estrogen combines with a large number of $\mathrm{ER} \alpha$ distributed in the genital organs, such as the breast and uterus, it can easily lead to breast cancer, endometrial cancer, and reproductive system cancer. Thus, drugs need to be identified that have no side effects and can selectively bind to ERs. Selective ER modulators (SERMs) have attracted widespread attention because of the avoidance of breast and reproductive system cancers induced by estrogen replacement therapy (ERT). SERMs include phytoestrogens (e.g., isoflavones) and ER $\beta$ selective agonists. Recent studies have shown that isoflavone improves glucolipid metabolism, reduces insulin resistance, and enhances cognitive function and anti-oxidation ability $(8,9)$. However, no such anti-diabetic cognitive impairment drugs are currently available.

Our group designed and synthesized a novel xanthones compound based on the structure of isoflavones named 3-p-tolyl-9H-xanthen-9-one (Tozan). It has a relative molecular mass of 286, and strong lip solubility. The structure was shown in Figure $1 \mathrm{~A}$ and confirmed by ${ }^{1} \mathrm{H}$ 
NMR and ${ }^{13} \mathrm{C}$ NMR. Our previous study found that Tozan had an obvious estrogen-like activity, and significantly improved the $\beta$-amyloid $(\mathrm{A} \beta)$ and hydrogen peroxide $\left(\mathrm{H}_{2} \mathrm{O}_{2}\right)$-induced cytotoxicity of PC12 cells. In this study, we used SH-SY5Y cells treated with methylglyoxal (MG), one of the most likely precursors of advanced glycation end-products (AGEs) among active carbonyl compounds largely accumulate in diabetes, to simulate a diabetic model in vitro (10). To induce a mouse model of diabetes, we also used streptozotocin (STZ) as a cytotoxic glucose analogue, which accumulates in pancreatic $\beta$ cells through glucose transporter 2, and results in absolute insulin deficiency (11). The effects and the possible mechanisms of Tozan were then investigated using these cell and mouse models. We present the following article in accordance with the ARRIVE reporting checklist (available at https://dx.doi.org/10.21037/ atm-21-4439).

\section{Methods}

\section{Cell cultures and treatments}

SH-SY5Y human neuroblastoma cells were purchased from Jiangsu Kaiji Biotechnology Co., Ltd. These cells were cultivated in Minimum Essential Medium/Ham's F 12 nutrient medium (MEM/F12) supplemented with $10 \%$ fetal bovine serum (Jiangsu Kaiji Biotechnology Co., Ltd.) at $37{ }^{\circ} \mathrm{C}$ with $5 \%$ carbon dioxide $\left(\mathrm{CO}_{2}\right)$. Cells in the logarithmic growth phase were digested into a singlecell suspension and inoculated into 96-well plates at a density of $5 \times 10^{4}$ cells $/ \mathrm{mL}$. After $24 \mathrm{~h}$ of culture, different concentrations of MG (Energy Chemical, Shanghai, China, $150,300,600$, and $1,200 \mu \mathrm{M}$ ) or medium of equal volumes was added to the cells. Cytotoxicity was then detected after 24, 48, and $72 \mathrm{~h}$. According to the experimental results (see Figure $1 B)$, the appropriate $M G$ concentration $(600 \mu \mathrm{M})$ and treatment time $(24 \mathrm{~h})$ were selected for the following experiments.

For the drug treatment experiment, the SH-SY5Y cells were divided into the following 5 groups: (I) Vehicle (Veh) + Veh; (II) MG + Veh; (III) MG + Tozan $2.5 \mu \mathrm{M}$; (IV) MG + Tozan $5 \mu \mathrm{M}$; and (V) MG + Tozan $10 \mu \mathrm{M}$. All groups were treated with MG $(600 \mu \mathrm{M})$ or medium of equal volume. After $24 \mathrm{~h}$, the cells were treated with different concentrations of Tozan $(2.5,5$, and $10 \mu \mathrm{M})$ or medium of equal volumes. Cytotoxicity and other biochemical indicators were then detected.

For the knockdown experiment, SH-SY5Y cells were divided into the following 4 groups: (I) Veh + Veh; (II) Veh + MG; (III) LV-ER $\beta$-ribonucleic acid interference (RNAi)

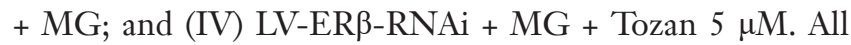
groups were treated with LV-ER $\beta$-RNAi (Genechem Co., Ltd., Shanghai, China, $20 \mu \mathrm{L}$ of viral suspension containing $1 \times 10^{7}$ vector) or medium of equal volume. After $24 \mathrm{~h}$, the cells were treated with $\mathrm{MG}(600 \mu \mathrm{M})$ or a medium of equal volume. After another $24 \mathrm{~h}$, the cells were treated with Tozan $(5 \mu \mathrm{M})$ or a medium of equal volume. Cytotoxicity and other biochemical indicators were then detected.

\section{Animal model and treatment}

Female Institute of Cancer Research mice, weighing 22-25 g (8-10 weeks old), were purchased from Yangzhou University Medical Center (Yangzhou, China). The mice were maintained under standard laboratory conditions (on a 12 -h light/dark cycle, at a temperature of $22 \pm 2{ }^{\circ} \mathrm{C}$ and humidity of $55 \% \pm 5 \%$ ) with free access to food and water. Experiments were performed under the project license (No.: SYXK2016-0011) granted by the ethics committee of China Pharmaceutical University, in compliance with the guidelines of the National Institutes of Health Guide for the Care and Use of Laboratory Animals. A protocol was prepared before the study without registration.

The mice were randomly divided into the following 6 groups ( $\mathrm{n}=20 /$ group): (I) Veh + Veh; (II) STZ \& ovariectomy (OVX) + Veh; (III) STZ\&OVX + Insulin (Ins); (IV) STZ\&OVX + Tozan $2.0 \mathrm{mg} / \mathrm{kg}$; (V) STZ\&OVX + Tozan $4.0 \mathrm{mg} / \mathrm{kg}$; and (VI) STZ\&OVX + Tozan $8.0 \mathrm{mg} / \mathrm{kg}$. In brief, except for those in the sham group, bilateral OVX surgeries were conducted on mice anesthetized with chloral hydrate $(350 \mathrm{mg} / \mathrm{kg}$, intraperitoneal injection) (1). One week later, mice in the T1DM animal model fasted for $12 \mathrm{~h}$ and were then intravenously administered STZ (150 mg/kg) (12) to induce hyperglycemia, with the exception of mice in the Veh + Veh group who were given a solvent of sodium citrate buffer $(0.1 \mathrm{M}, \mathrm{PH}=4.5)$ in equal volume. Three days later, mice whose fasting plasma glucose was $>11.0 \mathrm{mmol} / \mathrm{L}$ were regarded as diabetic and used in the next tests. Mice in Group (III) were subcutaneously administered 2 U/kg of insulin every day. Mice in Groups (IV), (V), and (VI) were intragastrically administered 2,4 , and $8 \mathrm{mg} / \mathrm{kg}$ of Tozan every day, respectively. The other groups were intragastrically administered with a vehicle $[0.5 \%$ sodium carboxymethyl cellulose (CMC-Na)] every day. All treatments were carried out for 4 weeks and the mice were then subjected to behavior and histopathological/ 
biochemical tests.

\section{MTT assay}

Four succinate dehydrogenase activity (MTT) assays were used to measure the ability of cells to metabolize MTT. At the end of the treatment period, the culture media were removed from each well, and $20 \mu \mathrm{L}$ of MTT (Aladdin Reagent Co., Ltd., Shanghai, China) solution $(5 \mathrm{mg} / \mathrm{mL})$ was added. After incubation at $37{ }^{\circ} \mathrm{C}$ for $2 \mathrm{~h}, 150 \mu \mathrm{L}$ of dimethyl sulfoxide was added to each well. The absorbance value at $492 \mathrm{~nm}$ of each well was then measured by an automatic microplate reader (CORONA SH-1000 Lab, Japan).

\section{Lactate dehydrogenase $(\mathrm{LDH})$ release assay}

To supplement the MTT assay, we used LDH assay kits (Nanjing Jiancheng Bioengineering Institute, Nanjing, China) to measure the LDH released from cells. After the cells had been exposed to different treatments, the total culture medium was collected and the amount of LDH released by the cells was determined in accordance with the manufacturer's protocol. The absorbance values at $440 \mathrm{~nm}$ of samples were measured by an automatic microplate reader (CORONA SH-1000 Lab, Japan).

\section{Morris water maze (MWM) tests}

MWM tests were used to assess the spatial learning and memory of the mice (13). The MWM apparatus was a circular pool (diameter: $120 \mathrm{~cm}$, height: $50 \mathrm{~cm}$ ), containing $30 \mathrm{~cm}$ of water, maintained at $25 \pm 1{ }^{\circ} \mathrm{C}$ with 4 separate quadrants in the different directions of north, east, west, and south. Visual cues were placed around the pool. The test consisted of 5 consecutive training days with visible and hidden platforms and a probe trial on the 6th day. During the visible-platform training sessions, a platform (diameter: $9 \mathrm{~cm}$ ) was fixed in the center of 1 quadrant and a flag (height: $5 \mathrm{~cm}$ ) was placed on the top of the visible platform (days 1-2). The flag was then removed and the platform hidden (days 3-5). Each mouse was exposed to 4 quadrants for 5 days, and there was a 1-hour interval between trials. Baseline differences in vision and motivation were detected in the visible-platform session, and the ability of spatial learning was assessed as the escape latency to find the platform during the hidden-platform test. Each trial lasted for $90 \mathrm{~s}$ unless the mouse reached the platform beforehand.
If a mouse failed to find the platform within $90 \mathrm{~s}$, the mouse was placed on the platform for $30 \mathrm{~s}$ manually. In the probe trial (day 6), the platform was removed and each mouse was allowed to swim for $90 \mathrm{~s}$ to search for the platform. A camera mounted over the center of the maze was attached to video tracking equipment (Viewer 2 Tracking Software; Ji Liang Instruments, China), and the time spent in the target quadrant (where the platform was previously located), the path length, the number of platform crossings, and the swim speed were obtained from the recorded tracings of the animal.

\section{Y-maze test}

The Y-maze test was performed as described before (13). The Y-maze apparatus consisted of 3 compartments set at a $120^{\circ}$ angle to each another and connected with passages. There was a floor of stainless-steel rods, which were the source of electricity. The trial, including the learning trial and the test trial, was conducted over 2 consecutive days. On the 1st day, each mouse was placed in 1 of the compartments and allowed to move freely for $5 \mathrm{~min}$ to habituate. After 5 min, 2 compartments were subject to electric shocks $(2 \mathrm{~Hz}, 125 \mathrm{~ms}, 10 \mathrm{~V})$ via the stainless-steel grid floor. Another compartment remained shock-free but a light was switched on for traction. If the mouse entered the shock-free compartment and stayed for $30 \mathrm{~s}$, the training would be stopped and a correct choice would be recorded. If the mouse failed to enter the correct compartment, it would be gently navigated to the shock-free compartment by hand and allowed to stay for $30 \mathrm{~s}$. Each mouse performed the same procedure 10 times. On the 2 nd day, the mice had 10 attempts to choose compartments without the adaptation phase. The number of correct choices during the 10 trials and the latency to enter the shock-free compartment were recorded manually.

\section{Open-field test}

The general locomotor activity of the mice associated with each treatment was reflected in the open-field test (13). The open-field chamber was made of Plexiglas, and measured $50 \mathrm{~cm}$ long, $50 \mathrm{~cm}$ wide, and $40 \mathrm{~cm}$ high. The experiments were conducted in a quiet environment with low-intensity light $(7 \mathrm{~lx})$. Each mouse was gently placed into the center of the box, and the recording started immediately after placement and lasted for $5 \mathrm{~min}$. Locomotor activity was observed for 5 min using ANY Maze ${ }^{\circledast}$ video tracking. The 
chamber was cleaned with $70 \%$ ethanol and dried with paper towels to eliminate any influence of odor before the next test.

\section{Western blot analysis}

After treatment, the cells were washed 3 times with $1 \mathrm{~mL}$ of cold phosphate-buffered saline (PBS), and $100 \mu \mathrm{L}$ of cell lysate buffer containing phenylmethylsulfonyl fluoride (PMSF: lysate $=1: 9$ ) was then added. The cells were scraped off, and the buffer was transferred to centrifuge tubes after lysing for $30 \mathrm{~min}$. The dissolved proteins were collected from the supernatant after centrifugation at a temperature of $4{ }^{\circ} \mathrm{C}, 12,000 \mathrm{rpm}$ for $5 \mathrm{~min}$. To determine the protein expression level of the hippocampus in diabetic mice, the tissue was dissected and immediately frozen on ice and chopped into small pieces, and then homogenized in a radioimmunoprecipitation assay buffer $[50 \mathrm{mM}$ of Tris (hydroxymethyl) aminomethane (THAM) hydrochloride (pH 7.4), $150 \mathrm{nM}$ of sodium chloride, $1 \mathrm{mM}$ of PMSF, $1 \mathrm{mM}$ of ethylenediamine tetraacetic acid, $1 \%$ of Triton X-100, $1 \%$ sodium deoxycholate, and $0.1 \%$ sodium dodecyl sulfate (SDS)]. After centrifugation of the homogenate at $4{ }^{\circ} \mathrm{C}, 12,000 \mathrm{rpm}$ for $15 \mathrm{~min}$, the dissolved proteins were gathered from the supernatant. Protein concentration was obtained using a bicinchoninic acid protein assay kit in accordance with the manual guidelines (Cat. No. P0010, Beyotime Biotechnology, Jiangsu, China). The extract was used to assess the protein expression of brain-derived neurotrophic factor (BDNF), pro- or cleaved caspase-3, B-cell lymphoma 2 (Bcl-2), Bcl-2-associated X protein (Bax), ERs, glyceraldehyde 3-phosphate dehydrogenase $(\mathrm{GAPDH})$, and $\beta$-actin.

Protein aliquot from each sample was run on $10-12 \%$ SDS-polyacrylamide gel electrophoresis and transferred to a polyvinylidene difluoride membrane, which was then blocked with $5 \%$ non-fat milk or $5 \%$ bovine serum albumin (BSA) in tris buffered saline-tween 20 (TBST) for $2 \mathrm{~h}$ at room temperature. The membranes were then incubated with the respective primary antibodies against BDNF (1:1,000, Cat. No. BS6533, Bioworld Technology), pro- or cleaved caspase-3 (1:500, Cat. No. 9665S, Cell Signaling Technology), Bcl-2 (1:500, Cat. No. BS1031, Boster Technology), Bax (1:500, Cat. No. BS1030, Boster Technology), ER $\alpha$ (1:1,000, Cat. No. SC-787, Santa Cruz Biotechnology), ER $\beta$ (1:1,000, Cat. No. SC-8974, Santa Cruz Biotechnology) GAPDH (1:8,000, Cat. No. AP0063, Bioworld Technology) or $\beta$-actin $(1: 10,000$, Cat. No.
AP0060, Bioworld Technology) at $4{ }^{\circ} \mathrm{C}$ overnight. After being washed 3 times in TBST, the membranes were incubated with a horseradish peroxidase (HRP)-conjugated secondary antibody (1:10,000, Cat. No. \#GGHL-15P, Bioworld Technology) for $2 \mathrm{~h}$ at room temperature and were visualized with an enhanced chemiluminescence detection reagents and a gel imaging system (Tanon Science \& Technology Co., Ltd., China).

The membrane, nuclear, and cytoplasmic proteins were obtained following the manufacturer's protocol of Membrane, Nuclear, and Cytoplasmic Protein Extraction kits (Cat. No. C510002, Sangon Biotech, China). The cytoplasmic protein extract was used to determine the level of phosphatidylinositol 3-kinase (PI3K; 1:1,000, Cat. No. BS3006, Bioworld Technology), p-PI3K (1:1,000, Cat. No. AP0152, Bioworld Technology), Akt (1:1,000, Cat. No. BS1810, Bioworld Technology) by western blot, and $\beta$-actin (1:10,000, Cat. No. AP0060, Bioworld Technology) was used as a loading control. The nuclear protein extract was used to determine the level of $\operatorname{ER} \alpha(1: 1,000$, Cat. No. SC-787, Santa Cruz Biotechnology), ER $\beta$ (1:1000, Cat. No. SC-8974, Santa Cruz Biotechnology), p-Akt (1:1,000, Cat. No. BS4007, Bioworld Technology), cAMP-response element binding protein (CREB; 1:1,000, Cat. No. BS1077, Bioworld Technology), phospho-CREB (p-CREB) (1:1,000, Cat. No. BS4053, Bioworld Technology), and lamin B1 (1:1,000, Cat. No. BS3547, Bioworld Technology) was used as a loading control. The membrane protein extract was used to determine the level of ER $\alpha$ (1:1,000, Cat. No. SC787, Santa Cruz Biotechnology), ER $\beta$ (1:1,000, Cat. No. sc-8974, Santa Cruz Biotechnology) by western blot, and GAPDH (1:8,000, Cat. No. AP0063, Bioworld Technology) was used as a loading control.

\section{Immunofluorescence staining}

After treatment, the SH-SY5Y cells $\left(5 \times 10^{4}\right.$ cells $\left./ \mathrm{mL}\right)$ were inoculated into 24-well plates and $10 \mu \mathrm{M}$ of 5-bromo-2'deoxyuridine (BrdU, Cat. No. B5002, Sigma-Aldrich) was added to the medium for $4 \mathrm{~h}$. The cells were fixed with $4 \%$ paraformaldehyde (PFA) at room temperature for $20 \mathrm{~min}$. The cells were then washed with PBS 3 times and permeabilized with $0.3 \%$ Triton X-100 for $30 \mathrm{~min}$. After being washed, the cells were blocked in a $10 \%$ goat serum albumin solution at room temperature for $1 \mathrm{~h}$, and then incubated in a solution of primary antibody $\operatorname{BrdU}(1: 200$, Cat. No. SC-56258, Santa Cruz) overnight at $4{ }^{\circ} \mathrm{C}$. On the 2nd day, after being washed with PBS 3 times, the cells 
were incubated with goat anti-rat immunoglobulin G (IgG; 1:200, Cat. No. A0507, Beyotime Biotechnology) secondary antibody for $1 \mathrm{~h}$ at room temperature. After being washed for another 3 cycles in PBS, the cells were incubated with 6-diamidino-2-phenylindole (DAPI) for 5-10 min, washed 3 times, and the sections were covered with coverslips. The cells were observed and captured under the Laser Scanning Confocal Microscope (LSM700, Carl Zeiss, Germany). A quantitative analysis was performed with Image-Pro Plus software.

The mice were injected with $50 \mathrm{mg} / \mathrm{kg}$ of $\mathrm{BrdU}$ (Cat. No. B5002, Sigma-Aldrich) 3 times intraperitoneally with an interval of $2 \mathrm{~h}$. After 2 weeks, the mice were deeply anesthetized and perfused transcardially with $0.1 \mathrm{M}$ of PBS followed by $4 \%$ PFA. The brains were post-fixed overnight in $4 \% \mathrm{PFA}$ at $4{ }^{\circ} \mathrm{C}$ and transferred to $30 \%$ sucrose to dehydrate over 2 days. Samples were cut into coronal sections $(10 \mu \mathrm{M})$ using an oscillating tissue slicer and then fixed on glass slides. Next, the sections were permeabilized with $0.3 \%$ Triton X-100 for $15 \mathrm{~min}$. After being washed 3 times with PBS, the sections were blocked with $10 \%$ goat serum albumin solution at room temperature for $1 \mathrm{~h}$, and then incubated in a solution of primary antibody BrdU (1:200, Cat. No. SC-56258, Santa Cruz) overnight at $4{ }^{\circ} \mathrm{C}$. On the $2 \mathrm{nd}$ day, after being washed with PBS 3 times, the sections were incubated with goat antirat IgG (1:200, Cat. No. A0507, Beyotime Biotechnology) secondary antibody for $1 \mathrm{~h}$ at room temperature. After being washed another 3 times in PBS, the sections were incubated with DAPI for 5-10 min, washed 3 times, and then covered with coverslips. The cells were observed and captured under the Laser Scanning Confocal Microscope (LSM700, Carl Zeiss, Germany). A quantitative analysis was performed using Image-Pro Plus software.

\section{Blood glucose and serum insulin determination}

The mice in each group fasted for $12 \mathrm{~h}$ before the blood glucose test. Blood samples $(10 \mu \mathrm{L})$ were drawn from the tail vein and the glucose concentrations were measured using the blood glucose monitoring system (Roche). Serum insulin concentrations were measured according to the mouse insulin enzyme-linked immunoassay (ELISA) kit instructions with the standard preparation (R\&D Systems, Suzhou, China). In brief, blood samples (approximately $800 \mu \mathrm{L}$ ) were taken from the orbit and centrifuged at 3,000 rpm for $15 \mathrm{~min}$ at $4{ }^{\circ} \mathrm{C}$. The supernatants were then collected. The sample $(10 \mu \mathrm{L})$ with the diluent $(40 \mu \mathrm{L})$ was added to the pre-coated plate, and $100 \mu \mathrm{L}$ HRP-conjugate reagent was then mixed in each well and incubated for $60 \mathrm{~min}$ at $37^{\circ} \mathrm{C}$ in the dark. After washing, chromogen was added to each well, which was then incubated at $37{ }^{\circ} \mathrm{C}$ in the dark for $15 \mathrm{~min}$. Finally, the stop solution was added and the resulting color was recorded at $450 \mathrm{~nm}$ using a microplate absorbance reader (CORONA SH-1000 Lab, Japan).

\section{Statistical analysis}

All the descriptive data are expressed as mean \pm standard error of mean (SEM). Behavioral data from the MWM tests were analyzed using 2-way repeated-measures analysis of variance (ANOVA) with "days" as the within-subject factor and "group" as the between-subject factor. The other data were analyzed using 1-way ANOVA followed by a Tukey or Dunnett's analysis for post-hoc multiple comparisons. A $\mathrm{P}<0.05$ was considered statistically significant. All analyses were conducted with SPSS 18.0.

\section{Results}

\section{Tozan ameliorates MG-induced cytotoxicity in SH-SYSY cells}

SH-SY5Y cells were treated with different concentrations of MG $(150,300,600$, and $1,200 \mu \mathrm{M})$ for 24,48 , and $72 \mathrm{~h}$, and the survival rate was then determined by a MTT assay. The results showed that the survival rate of the SHSY5Y cells decreased with the increase of MG concentration and reaction time. When $600 \mu \mathrm{M} \mathrm{MG}$ was used to treat $5 \times 10^{4} / \mathrm{mL}$ SH-SY5Y cells for $24 \mathrm{~h}$, the cell survival rate was $56.92 \% \pm 3.10 \%$, which was significantly different to that of the control group $(\mathrm{P}<0.01)$, and significant cell damage was observed (see Figure 1B). Concentration and reaction time were selected for modeling in the subsequent experiments.

The effects of Tozan on MG-induced SH-SY5Y cell damage and cell viability were determined for each group by MTT assay. As Figure $1 C$ shows, compared to the control group, the cell survival rate decreased significantly after treatment with $600 \mu \mathrm{M} \mathrm{MG}$ for $24 \mathrm{~h}(\mathrm{P}<0.01)$, while the survival rate of cells treated with different doses of Tozan $(10,5$, and $2.5 \mu \mathrm{M})$ increased significantly $(\mathrm{P}<0.05$ or $\mathrm{P}<0.01)$. To confirm these results, we examined the release of LDH in the SH-SY5Y cells. As Figure 1D shows, compared to the control group, a large amount of $\mathrm{LDH}$ was released after treatment with $600 \mu \mathrm{M} \mathrm{MG}(\mathrm{P}<0.01)$, and different doses of Tozan $(10,5$, and $2.5 \mu \mathrm{M})$ reversed the changes $(\mathrm{P}<0.05$ or $\mathrm{P}<0.01)$. In addition, Tozan $(10,5$, and 
$2.5 \mu \mathrm{M})$ had no effect on the survival rate of the SH-SY5Y cells $(\mathrm{P}>0.05$; see Figure 1C,1D).

\section{Tozan ameliorates cognitive deficits in diabetic mice}

To investigate the effects of Tozan on learning and cognition in STZ-induced type 1 diabetic mice, different behavioral tests were performed on mice after modeling and administration. First, we used the MWM task to test the differences in learning and memory between groups. There was no significant difference between the escape latency of mice in each group during the visible-platform training session $(\mathrm{P}>0.05$; see Figure $2 A)$, indicating that mice in the different groups had normal object recognition ability and cognitive ability. During the hidden-platform training period, the latency of the STZ\&OVX + Veh group was significantly increased compared to that of the other groups; however, this group showed a remarkable decrease in latency after treatment with Tozan $(4.0 \mathrm{mg} / \mathrm{kg})$ on day 5 $(\mathrm{P}<0.05$; see Figure $2 B)$. On day 6 of the space exploration experiment, mice in the STZ\&OVX + Veh group spent significant less time in the target quadrant $(\mathrm{P}<0.01$; see Figure $2 C$ ) and had fewer platform location crossings $(\mathrm{P}<0.01$; see Figure 2D) compared to the Veh + Veh group . After Tozan treatment, the time spent in the target quadrant and the number of platform location crossings increased significantly $(\mathrm{P}<0.05$ or $\mathrm{P}<0.01$; see Figure $2 C, 2 D)$. The representative swim paths of each group on day 6 are shown in Figure 2E.

To further investigate the ability of mice to learn and remember, the Y-maze test was conducted. The results showed that the latency to enter the shock-free compartment of the STZ\&OVX + Veh group was significantly greater than that of the Veh + Veh group $(\mathrm{P}<0.01$; see Figure $2 F)$, and the number of correct choices in the STZ\&OVX + Veh group was significantly reduced $(\mathrm{P}<0.01$; see Figure $2 G)$. Compared to the STZ\&OVX + Veh group, the latency to enter the shock-free compartment of the Tozan treatment group (2, 4, and $8 \mathrm{mg} / \mathrm{kg}$ ) was significantly decreased $(\mathrm{P}<0.05$ or $\mathrm{P}<0.01$; see Figure $2 F)$, and the correct times were significantly increased $(\mathrm{P}<0.05$ or $\mathrm{P}<0.01$; see Figure $2 G$ ). These data provide further evidence that Tozan ameliorates cognitive deficits in type 1 diabetic mice.

The locomotor activity of mice in each group was examined by the open-field test. The results showed that there were no significant differences between the groups in the movement distance of the test chamber $(\mathrm{P}>0.05$; see Figure $2 H$ ), indicating that there were no significant differences in the spontaneous activities of mice in each group. These results indicate that Tozan can significantly improve the learning and cognitive functions of type 1 diabetic mice without affecting spontaneous activity.

\section{Tozan increases the number of newborn cells in vitro and in vivo}

BrdU is a pyrimidine nucleoside analogue that can be incorporated into the newly synthesized deoxyribonucleic acid (DNA) of replicating cells in place of thymine during the DNA synthesis phase (14). We added BrdU to the cell medium and determined the effects of Tozan on MGinduced SH-SY5Y cell proliferation by immunofluorescence staining with an anti-BrdU specific antibody. As Figure $3 A, 3 B$ shows, the proportion of new cells in the model group was significantly decreased compared to that of the control group $(\mathrm{P}<0.01)$, while the number of new cells was significantly increased after Tozan treatment $(2.5,5$, and $10 \mu \mathrm{M} ; \mathrm{P}<0.05$ or $\mathrm{P}<0.01)$.

To study the effects of Tozan on nerve regeneration in the dentate gyrus of type 1 diabetic mice, BrdU was used as a marker and immunofluorescence was used to detect the number of newborn cells in the dentate gyrus of the hippocampus of the mice. The experimental results showed that compared to the Veh + Veh group, the number of newborn cells in the dentate gyrus of the STZ\&OVX + Veh group was significantly decreased $(\mathrm{P}<0.01$; see Figure $3 C, 3 D)$. After Tozan $(2,4$, and $8 \mathrm{mg} / \mathrm{kg})$ treatment, the number of newborn cells in the dentate gyrus of the hippocampus was significantly higher than that of the STZ\&OVX + Veh group $(\mathrm{P}<0.05$ or $\mathrm{P}<0.01$; see Figure $3 C, 3 D)$. These results suggest that Tozan can ameliorate cognitive deficits in type 1 diabetic mice by promoting the nerve regeneration of cells in the brain hippocampus region.

BDNF is a neurotrophic factor that plays an important role in nerve regeneration. To further investigate the effects of Tozan on nerve regeneration in type 1 diabetic mice, we examined the expression level of the BDNF protein in the hippocampus of mice by western blot. The results showed that the expression level of the BDNF protein in the hippocampus of the STZ\&OVX + Veh group was significantly decreased compared to that of the Veh + Veh group $(\mathrm{P}<0.01)$, while Tozan $(2,4$, and $8 \mathrm{mg} / \mathrm{kg})$ significantly improved the decrease of BDNF expression caused by STZ $(\mathrm{P}<0.05$ or $\mathrm{P}<0.01$; see Figure $3 E, 3 F)$. 

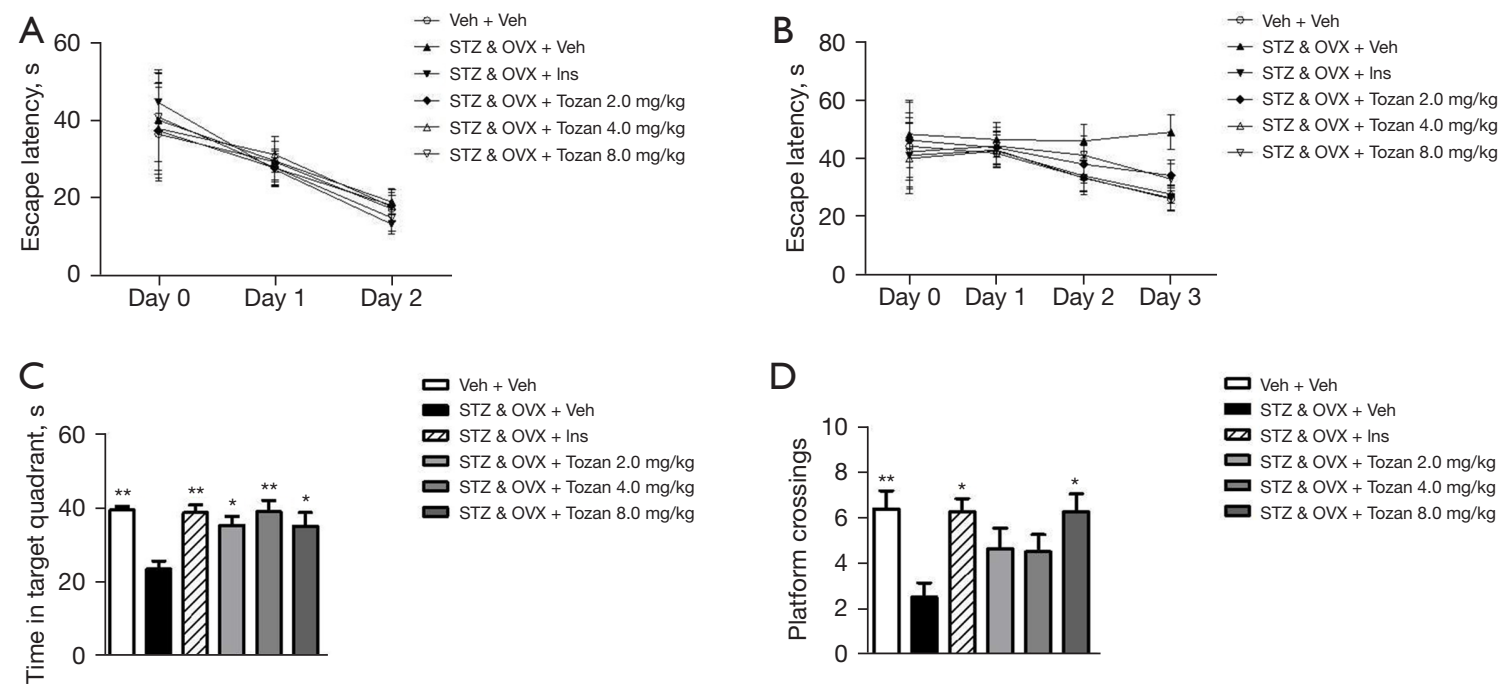

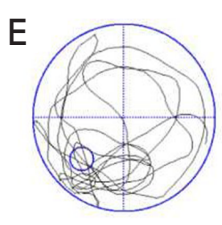

Veh + Veh

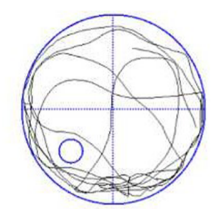

STZ \& OVX + Veh

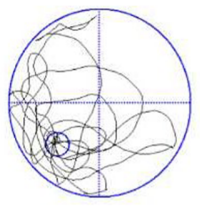

$\mathrm{STZ} \& \mathrm{OVX}+\mathrm{Ins}$ $2 \mathrm{U} / \mathrm{kg}$

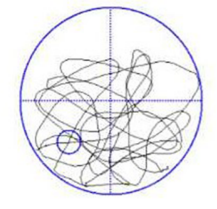

STZ \& OVX + ToZ $2.0 \mathrm{mg} / \mathrm{kg}$

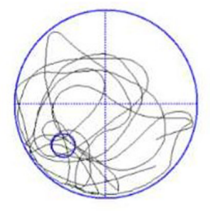

STZ \& OVX + Toz $4.0 \mathrm{mg} / \mathrm{kg}$

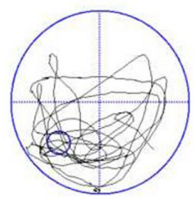

STZ \& OVX + Tozan $8.0 \mathrm{mg} / \mathrm{kg}$

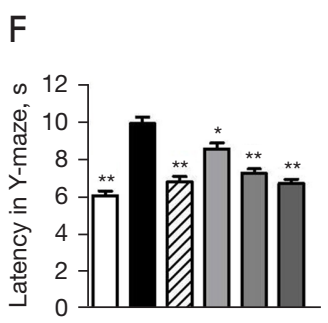

\section{G} Veh + Veh
STZ \& OVX + Veh
STZ \& OVX + Ins

口 STZ \& OVX + Tozan $2.0 \mathrm{mg} / \mathrm{kg}$ 口 STZ \& OVX + Tozan $4.0 \mathrm{mg} / \mathrm{kg}$ ص STZ \& OVX + Tozan 8.0 mg/kg

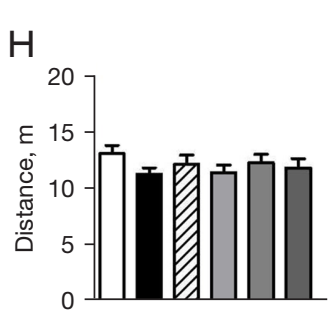

口 Veh + Veh

- STZ\& OVX + Veh

ש STZ \& OVX + Ins

D STZ \& OVX + Tozan $2.0 \mathrm{mg} / \mathrm{kg}$

口 STZ \& OVX + Tozan $4.0 \mathrm{mg} / \mathrm{kg}$

口 STZ \& OVX + Tozan $8.0 \mathrm{mg} / \mathrm{kg}$

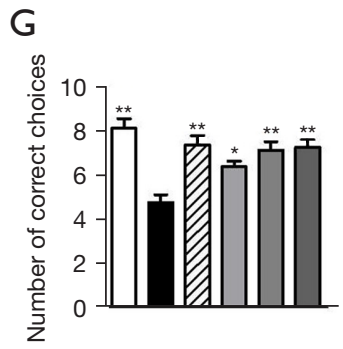

$\square$ Veh + Veh

- STZ \& OVX + Veh

ש STZ \& OVX + Ins

口TT \& OVX + Tozan $2.0 \mathrm{mg} / \mathrm{kg}$

口TTZ \& OVX + Tozan $4.0 \mathrm{mg} / \mathrm{kg}$

GTZ \& OVX + Tozan $8.0 \mathrm{mg} / \mathrm{kg}$

Figure 2 Tozan ameliorates cognitive deficits in type 1 diabetic mice. Day 0 indicated performance on the first trial in the MWM task and subsequent points represent an average of all daily trials. (A) There was no significant difference in the escape latency among all the groups (days 1-2). (B) Changes in escape latency to reach the hidden platform during acquisition trials (days 3-5). (C,D) The times spent by all groups in the target quadrant and their platform crossing numbers. (E) The representative swim paths of each group on day 6. (F,G) The latency to enter the shock-free component and the correct choices of all groups on day 2 in the Y-maze task. (H) The movement distance of each group in OFT. Data are shown as means $\pm \mathrm{SEM}(\mathrm{n}=8) .{ }^{*} \mathrm{P}<0.05,{ }^{* *} \mathrm{P}<0.01$ vs. STZ\&OVX + Veh group. MWM, Morris water maze; OFT, open field test; SEM, standard error of mean. 


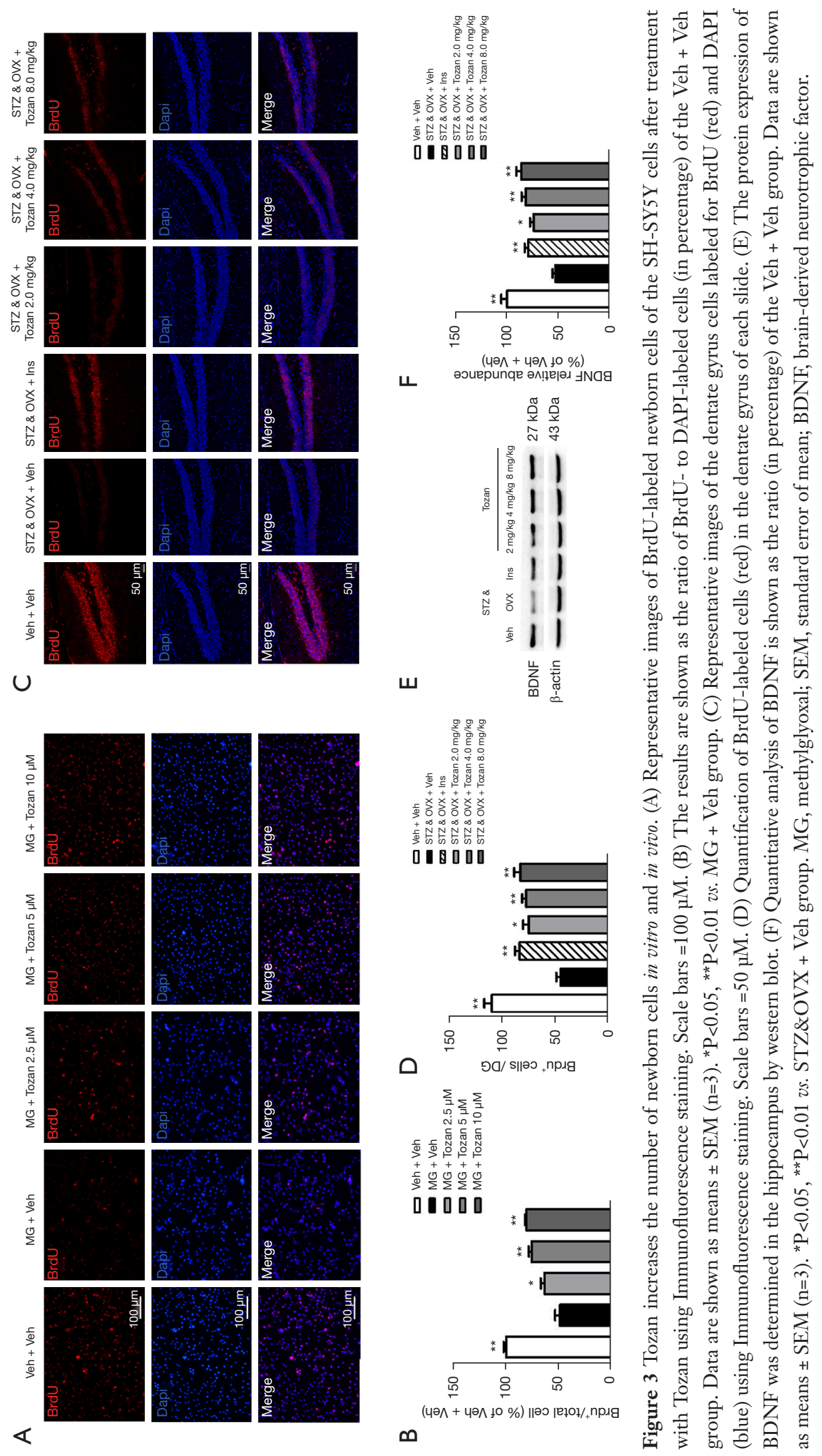


A

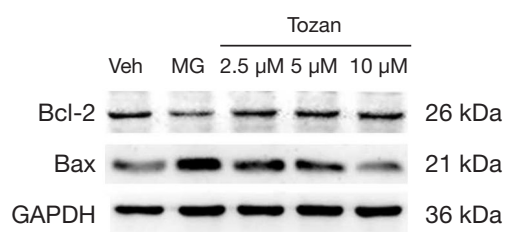

C

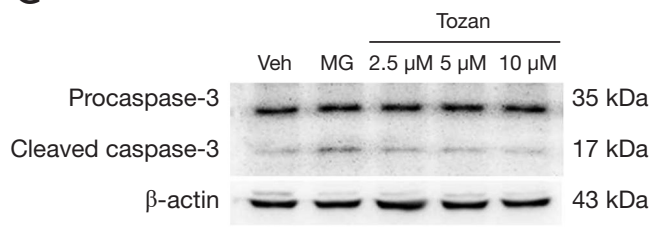

E

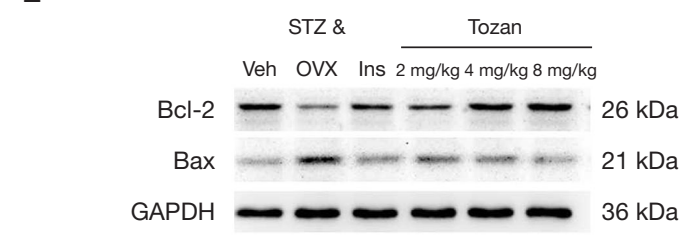

G

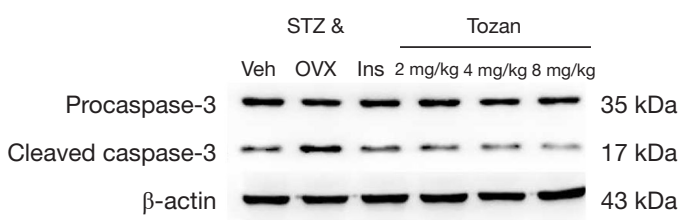

B

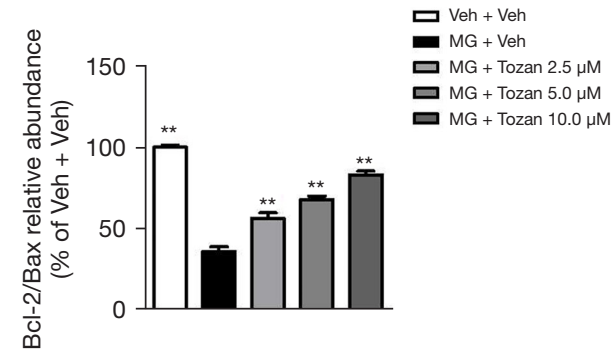

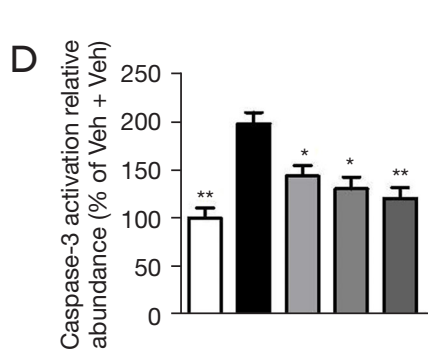

चeh + Veh

- $M G+V e h$

口 $M G+$ Tozan $2.5 \mu \mathrm{M}$

口 MG + Tozan $5.0 \mu \mathrm{M}$

口 MG + Tozan $10.0 \mu \mathrm{M}$

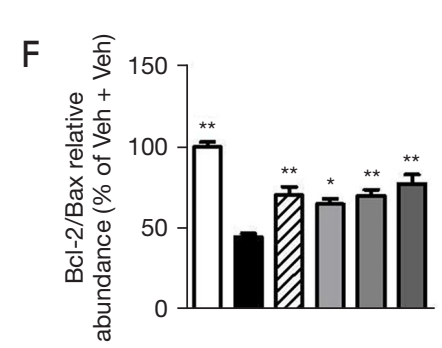

Veh + Veh

STZ \& OVX + Veh

STZ\& OVX + Ins

STZ \& OVX + Tozan $2.0 \mathrm{mg} / \mathrm{kg}$

口 STZ \& OVX + Tozan $4.0 \mathrm{mg} / \mathrm{kg}$

口 STZ \& OVX + Tozan 8.0 mg/kg

$\mathrm{H}$

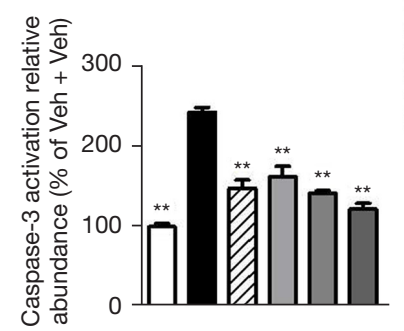

שeh + Veh

STZ \& OVX + Veh

DTZ \& OVX + Tozan $2.0 \mathrm{mg} / \mathrm{kg}$

口 STZ \& OVX + Tozan $4.0 \mathrm{mg} / \mathrm{kg}$

STZ \& OVX + Tozan $8.0 \mathrm{mg} / \mathrm{kg}$

Figure 4 Tozan prevents apoptotic responses in vivo and in vitro. (A) The protein expression of Bcl-2 and Bax in SH-SY5Y cells was determined by western blot. (B) Quantification of Bcl-2/Bax is shown as the ratio (in percentage) of the Veh + Veh group. (C) The protein expression of procaspase-3 and cleaved caspase-3 in SH-SY5Y cells was detected by western blot. (D) Quantification of cleaved caspase-3/ procaspase- 3 is shown as the ratio (in percentage) of the Veh + Veh group. Data are shown as means $\pm \operatorname{SEM}(\mathrm{n}=3)$. ${ }^{*} \mathrm{P}<0.05$, ${ }^{* *} \mathrm{P}<0.01$ vs. MG + Veh group. (E) The protein levels of Bcl-2 and Bax in the hippocampus of each group were determined by western blot. (F) Quantification of Bcl-2/Bax is shown as the ratio (in percentage) of the Veh + Veh group. (G) The protein levels of procaspase- 3 and cleaved caspase- 3 in the hippocampus of each group were determined by western blot. $(\mathrm{H})$ Quantification of cleaved caspase-3/procaspase-3 is shown as the ratio (in percentage) of the Veh + Veh group. Data are shown as means $\pm \operatorname{SEM}(\mathrm{n}=3) .{ }^{*} \mathrm{P}<0.05,{ }^{* *} \mathrm{P}<0.01$ vs. STZ\&OVX + Veh group. SEM, standard error of mean.

\section{Tozan prevents apoptotic responses in vitro and in vivo}

Apoptosis is also an important mechanism in the treatment of memory disorders. Apoptosis-related proteins include Bcl-2, Bax, and Caspase-3. The results of the western blot analysis showed that the $\mathrm{Bcl}-2 / \mathrm{Bax}$ ratio was significantly decreased in MG-induced SH-SY5Y cells $(\mathrm{P}<0.01$; see Figure $4 A, 4 B)$. However, Tozan $(2.5,5$, and $10 \mu \mathrm{M})$ treatment reversed these changes $(\mathrm{P}<0.01$; see Figure $4 A, 4 B)$. In addition, the activation level of Caspase- 3 protein in 

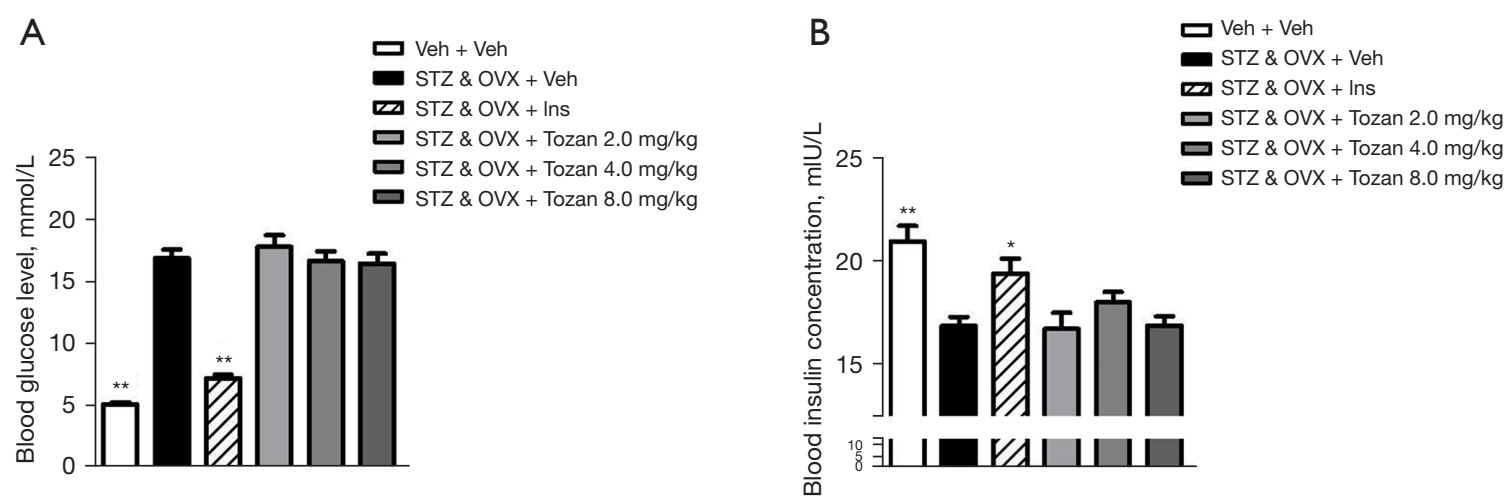

Figure 5 Effects of Tozan on fasting blood glucose and the serum insulin levels in type 1 diabetic mice. (A,B) There was no significant difference in the fasting blood glucose and serum insulin levels of the mice treated by Tozan. Data are shown as means \pm SEM ( $=6$ ). ${ }^{*} \mathrm{P}<0.05,{ }^{* *} \mathrm{P}<0.01$ vs. STZ\&OVX + Veh group. SEM, standard error of mean.

the model group was significantly increased $(\mathrm{P}<0.01$; see Figure $4 C, 4 D)$, while it was significantly reduced after Tozan treatment $(2.5,5$, and $10 \mu \mathrm{M})(\mathrm{P}<0.05$ or $\mathrm{P}<0.01$; see Figure $4 C, 4 D$ ). These results showed that the anti-apoptotic effects of Tozan improve MG-induced SH-SY5Y cell injury.

To investigate the effects of Tozan on apoptosis in the hippocampus of type 1 diabetic mice, we measured the expression levels of apoptosis-related proteins Bcl2, Bax, and caspase- 3 in the hippocampus of mice in each group. As Figure $4 E-4 H$ shows, the ratio of Bcl-2/Bax in the hippocampus of mice in the STZ\&OVX + Veh group was significantly decreased compared to that of the Veh + Veh group $(\mathrm{P}<0.01)$, while the activation of caspase- 3 was significantly increased $(\mathrm{P}<0.01)$. However, Tozan $(2$, 4 , and $8 \mathrm{mg} / \mathrm{kg}$ ) treatment reversed these changes $(\mathrm{P}<0.05$ or $\mathrm{P}<0.01)$. These results suggest that Tozan improves the cognitive deficits of type 1 diabetic mice by inhibiting apoptosis in the hippocampus.

\section{Effects of Tozan on blood glucose and serum insulin in diabetic mice}

We then tested the blood glucose and serum insulin levels of mice in each group. As Figure $5 A, 5 B$ shows, we found that the blood glucose level of mice in the STZ\&OVX + Veh group was increased significantly and the serum insulin level was decreased significantly compared to that of the Veh + Veh group $(\mathrm{P}<0.01)$. There was no significant difference in the blood glucose and insulin levels of the STZ\&OVX + Ins and Veh + Veh groups $(\mathrm{P}>0.05)$. However, the Tozan $(2,4$, and $8 \mathrm{mg} / \mathrm{kg}$ ) treatment did not change the blood glucose and serum insulin levels of the STZ-induced mice.

\section{Effects of Tozan on the ERs expression}

The expression of ER $\alpha$ and ER $\beta$ in each group was detected by western blot. Compared to the control group, the protein expression of $\mathrm{ER} \alpha$ and $\mathrm{ER} \beta$ was significantly decreased after $M G$ treatment $(\mathrm{P}<0.01$; see Figure $6 A-6 C)$. The expression level of ER $\beta$ was significantly increased in the Tozan treatment $(2.5,5$, and $10 \mu \mathrm{M})$ group compared to the model group $(\mathrm{P}<0.05$ or $\mathrm{P}<0.01)$; however, Tozan had no significant effect on ER $\alpha$ protein expression $(\mathrm{P}>0.05)$.

We then tested the effects of Tozan on ER expression level in the hippocampus of STZ-induced type 1 diabetic mice. Compared to the Veh + Veh group, the expression levels of ER $\alpha$ and ER $\beta$ proteins in the cell membrane and nucleus of the STZ\&OVX + Veh group were significantly decreased $(\mathrm{P}<0.01$; see Figure $6 D-6 G)$. Compared to the STZ\&OVX + Veh group, the expression level of ER $\beta$ protein in the cell membrane was significantly increased after different doses of Tozan (2, 4, and $8 \mathrm{mg} / \mathrm{kg}$ ) were administered $(\mathrm{P}<0.01)$. In addition, a high dose of Tozan $(8 \mathrm{mg} / \mathrm{kg})$ significantly increased the nuclear $\mathrm{ER} \beta$ protein level in the hippocampus $(\mathrm{P}<0.05)$. However, Tozan $(2,4,8 \mathrm{mg} / \mathrm{kg})$ had no significant effect on $\mathrm{ER} \alpha$ protein expression in the cell membrane and nucleus of the hippocampus $(\mathrm{P}>0.05)$.

\section{Tozan activates $P I 3 K / A k t, C R E B$, and BDNF signaling in diabetic mice}

Previous research has shown that the ligand activation of ERs can directly or indirectly activate CREB $(15,16)$. We examined the effects of Tozan on the PI3K/Akt-CREB 
A
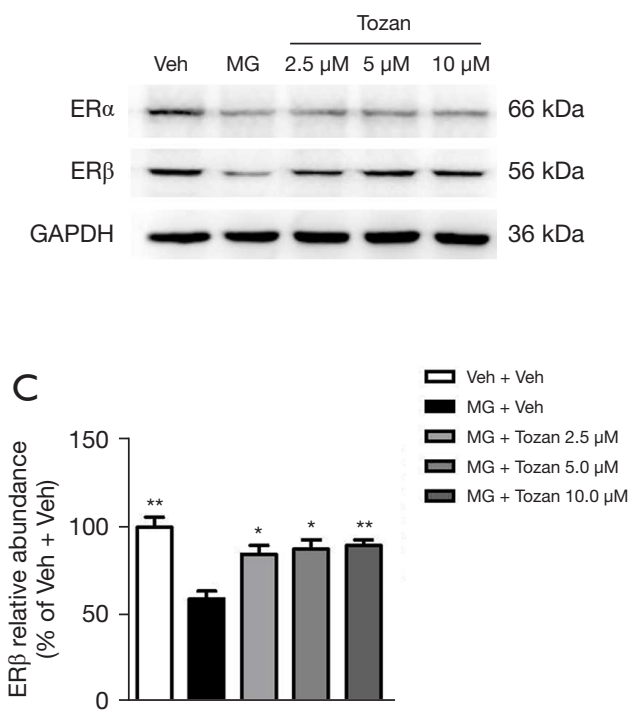

D
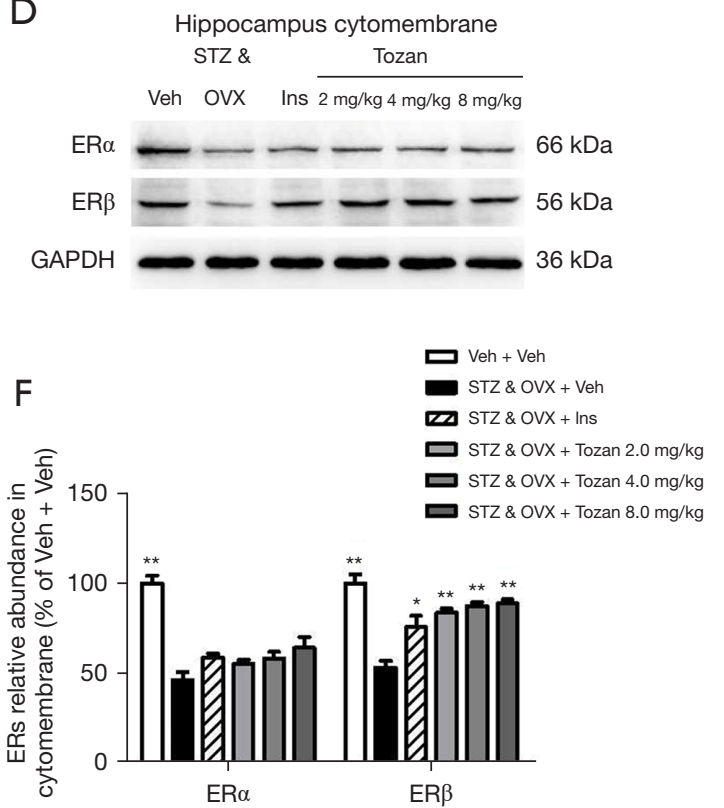

B

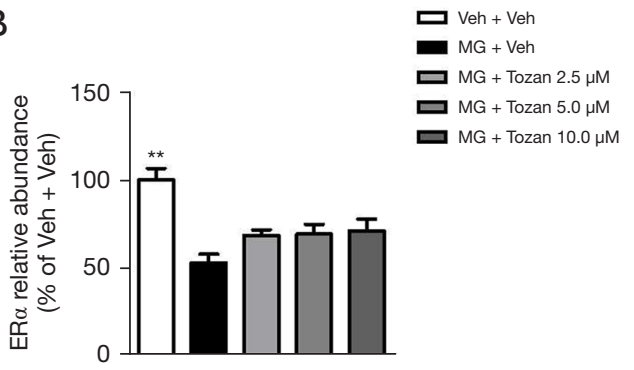

$\mathrm{E}$

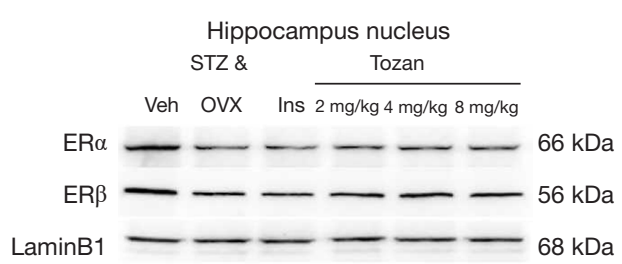

G
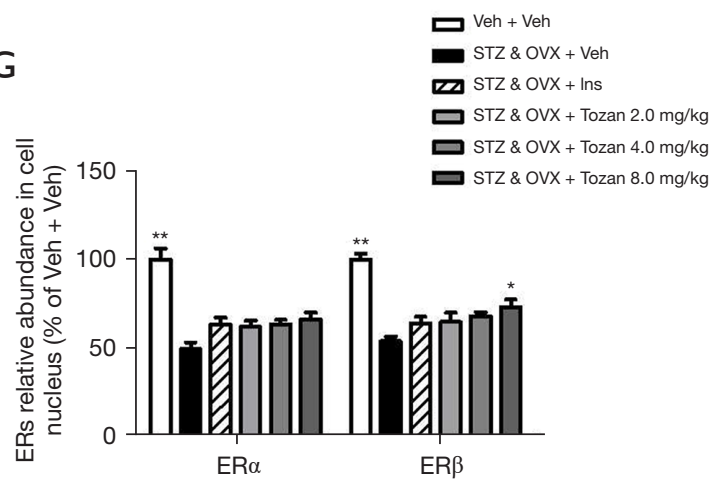

Figure 6 Effects of Tozan on the expression of ERs. (A) The protein expression of ER $\alpha$ and ER $\beta$ in SH-SY5Y cells was detected by western blot. (B,C) The quantification of ER $\alpha$ and ER $\beta$ in SH-SY5Y cells is shown as the ratio (in percentage) of the Veh + Veh group. Data are shown as means $\pm \operatorname{SEM}(\mathrm{n}=3) .{ }^{*} \mathrm{P}<0.05,{ }^{* *} \mathrm{P}<0.01$ vs. MG + Veh group. $(\mathrm{D}, \mathrm{E})$ The protein expression of $\mathrm{ER} \alpha$ and $\mathrm{ER} \beta$ in the cytomembrane and nucleus of the hippocampus was detected by western blot. (F,G) The quantification of ER $\alpha$ and ER $\beta$ is shown as the ratio (in percentage) of the Veh + Veh group. Data are shown as means \pm SEM $(\mathrm{n}=3) .{ }^{*} \mathrm{P}<0.05,{ }^{* *} \mathrm{P}<0.01$ vs. STZ\&OVX + Veh group. ER, estrogen receptor; $M G$, methylglyoxal; SEM, standard error of mean.

signaling pathway by western blot. As Figure $7 A-7 D$ show, the protein expression levels of p-PI3K/PI3K, p-Akt/Akt, and p-CREB/CREB in the hippocampus of the STZ\&OVX + Veh group were significantly decreased compared to the Veh + Veh group $(\mathrm{P}<0.01)$. The administration of Tozan $(2,4$, and $8 \mathrm{mg} / \mathrm{kg})$ reversed the 

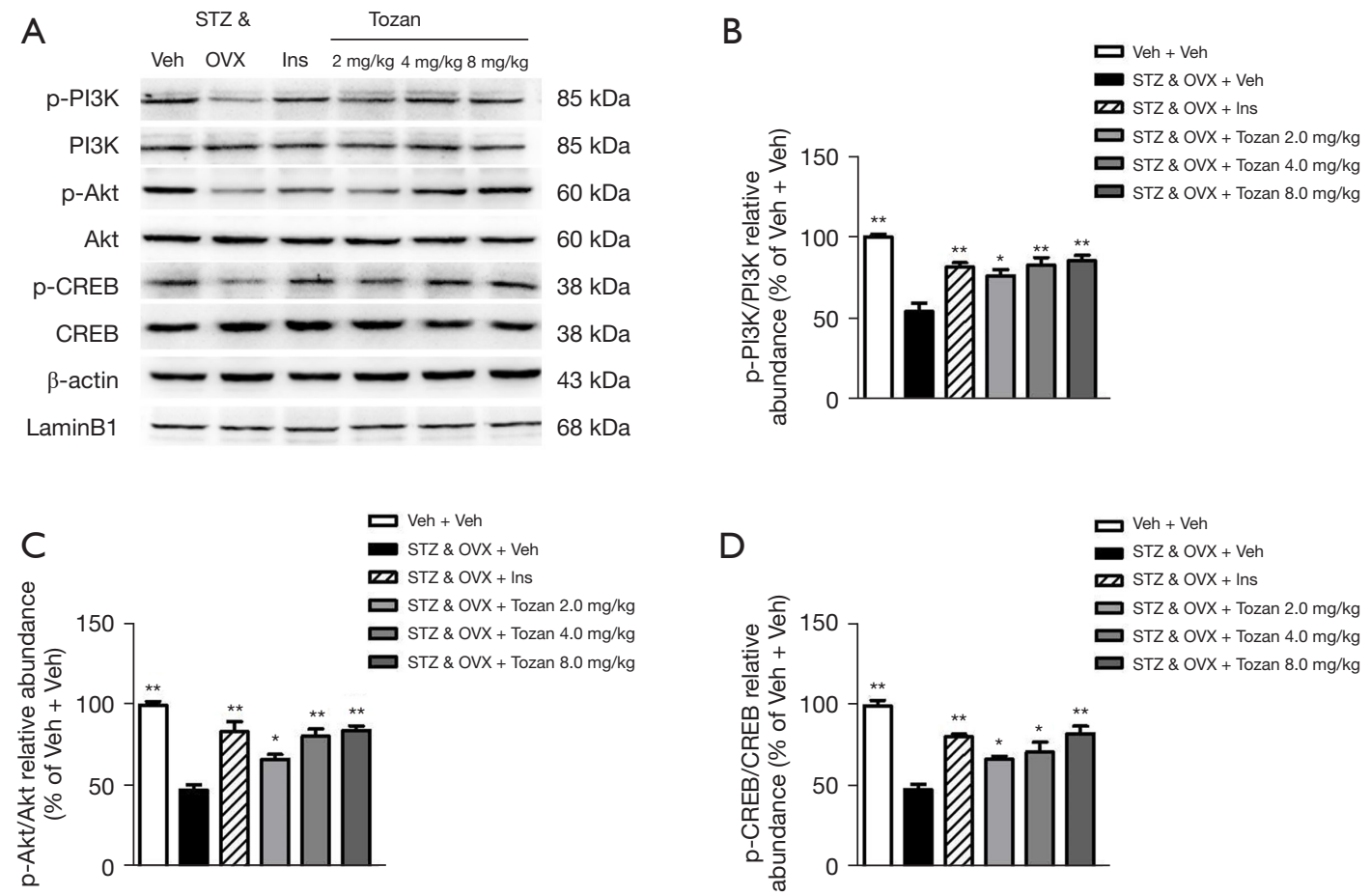

Figure 7 Tozan activates PI3K/Akt-CREB signaling in the hippocampus of type 1 diabetic mice. (A) The protein expression of p-PI3K/ PI3K, p-Akt/Akt, and p-CREB/CREB in the hippocampus was determined by western blot. (B-D) The results of the quantitative analysis of p-PI3K/PI3K, p-Akt/Akt, and p-CREB/CREB are shown as the ratio (in percentage) of the Veh + Veh group. Data are shown as means \pm $\operatorname{SEM}(\mathrm{n}=3) .{ }^{*} \mathrm{P}<0.05,{ }^{* *} \mathrm{P}<0.01$ vs. STZ\&OVX + Veh group. SEM, standard error of mean.

STZ-induced decrease in the expression levels of p-PI3K/ $\mathrm{PI} 3 \mathrm{~K}$, p-Akt/Akt, and p-CREB/CREB in the hippocampus $(\mathrm{P}<0.05$ or $\mathrm{P}<0.01)$. Based on these results, we speculated that Tozan mainly activates CREB through the PI3K/AktCREB pathway, a high dose of Tozan $(8 \mathrm{mg} / \mathrm{kg})$ activates CREB through the nuclear ER $\beta$, and thus plays a role in anti-apoptosis and neurogenesis.

\section{Tozan has no effect on cognition, neurogenesis, and apoptosis in the ERß knockdown cells model}

To further demonstrate that Tozan ameliorates neuroprotective effects through ER $\beta$, we used Lentiviral short hairpin RNA (shRNA)-mediated knockdown to silence the ER $\beta$ gene in the SH-SY5Y cells. As Figure $8 A, 8 B$ shows, the ER $\beta$ gene silencing efficiency in SH-SY5Y cells was more than $70 \%$, indicating that the cell model was successfully constructed. Compared to the LV-ER $\beta$-RNAi + MG group, Tozan treatment did not change the ER $\beta$ protein expression and cytotoxicity in MG-induced ER $\beta$ knockdown SH-SY5Y cells $(\mathrm{P}>0.05$; see Figure $8 C-8 H)$. Additionally,
Tozan treatment did not significantly decrease the activation of caspase- 3 protein and did not significantly increase the ratio of $\mathrm{Bcl}-2 / \mathrm{Bax}$, the number of $\mathrm{BrdU}^{+}$cells, and $\mathrm{BDNF}$ expression in MG-induced ER $\beta$ knockdown SH-SY5Y cells ( $>0.05$; see Figure 9). Finally, we found Tozan treatment did not increase the levels of p-PI3K/PI3K, p-Akt/Akt, and p-CREB/CREB in MG-induced ER $\beta$ knockdown SH-SY5Y cells compared to the LV-ER $\beta-R N A i+M G$ group $(\mathrm{P}>0.05$; see Figure 10). These results indicate that Tozan appears to meliorate cognitive impairment, neurogenesis, and apoptosis through ER $\beta$ in type 1 diabetes.

\section{Discussion}

We found that Tozan significantly improved the learning and cognitive function of STZ-induced type 1 diabetic mice, exerted anti-apoptotic effects, and promoted neurogenesis in vivo and in vitro. Tozan mediated PI 3 K/Akt-CREB signaling by activating membrane ER $\beta$ and high doses of Tozan mediated CREB signaling by activating nuclear ER $\beta$ in the hippocampus to ameliorate cognitive dysfunction in 
A
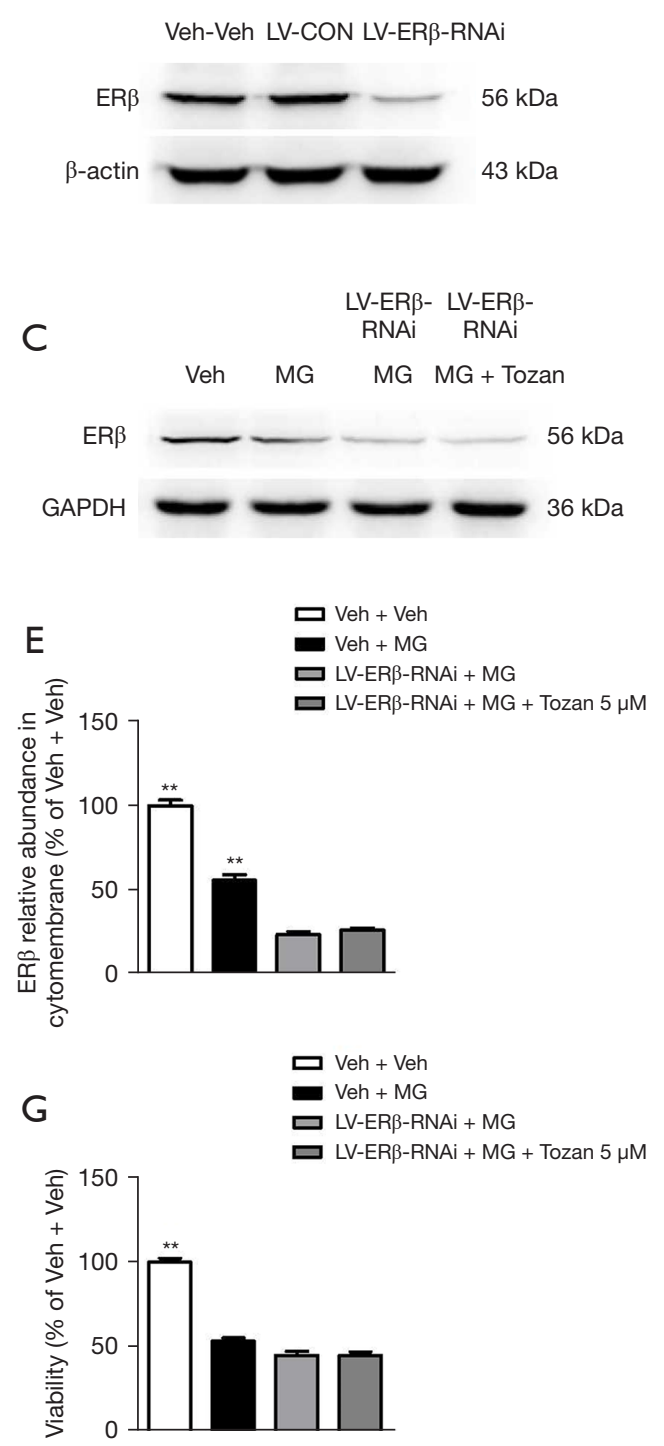

B
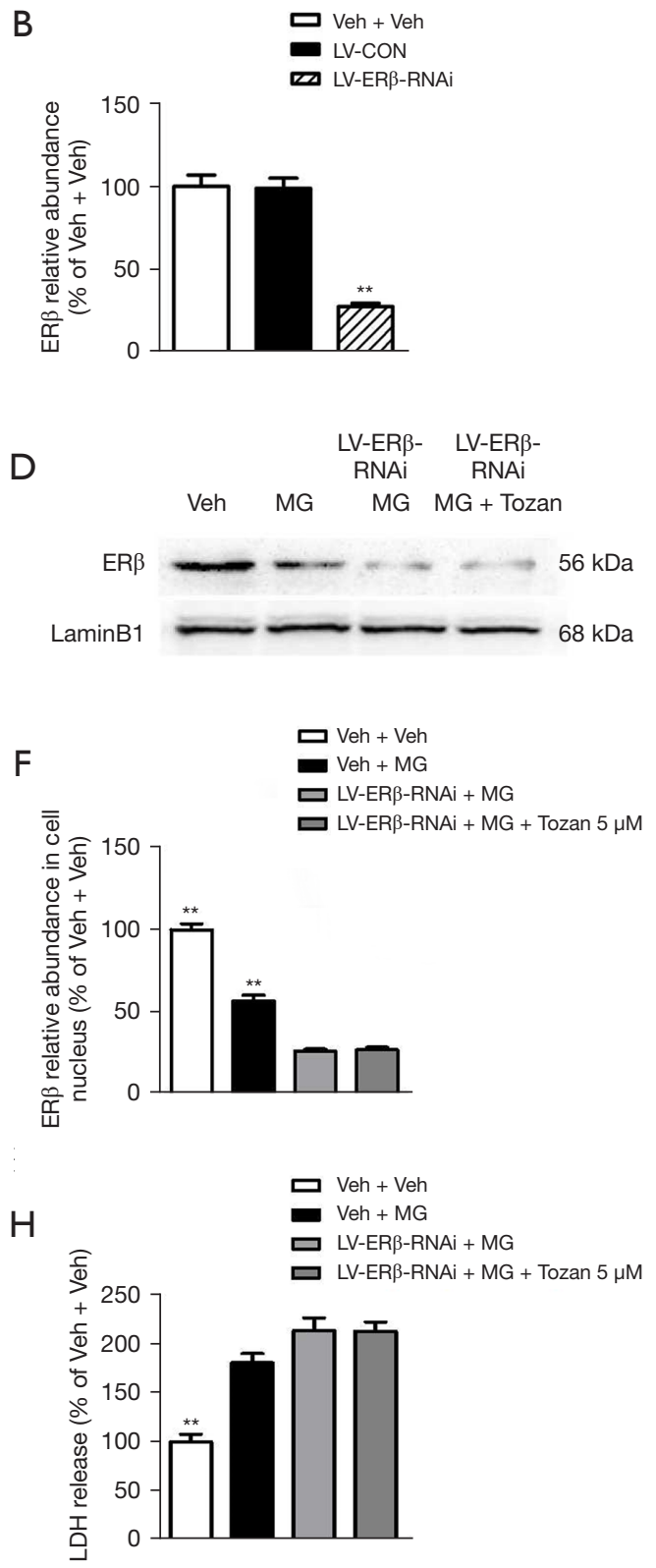

Figure 8 Effects of Tozan on the expression of ER $\beta$ in cytomembrane and nucleus and cytotoxicity in the MG-induced ER $\beta$ knockdown SH-SY5Y cells. (A) The protein expression of ER $\beta$ in each group was detected by western blot. (B) The quantification of ER $\beta$ in the cells is shown as the ratio (in percentage) of the Veh + Veh group. Data are shown as means $\pm \operatorname{SEM}(\mathrm{n}=3)$. ${ }^{* *} \mathrm{P}<0.01 v s$. Veh + Veh group. (C,D) The protein expression of ER $\beta$ in the cytomembrane and nucleus in all groups was detected by western blot. (E,F) The quantification of $\mathrm{ER} \beta$ in the cytomembrane and nucleus is shown as the ratio (in percentage) of the Veh + Veh group. Data are shown as means \pm SEM ( $n=3)$. ${ }^{*} \mathrm{P}<0.01$ vs. LV-ER $\beta$-RNAi + MG group. (G,H) Effects of Tozan on the injury of ER $\beta$ knockdown SH-SY5Y cells induced by MG. Results were evaluated by the MTT reduction and LDH release assays in different groups. Data are shown as means $\pm \mathrm{SEM}(\mathrm{n}=6) .{ }^{* *} \mathrm{P}<0.01$ vs. $\mathrm{LV}$ ER $\beta-R N A i+M G$ group. ER, estrogen receptor; MG, methylglyoxal; SEM, standard error of mean. 

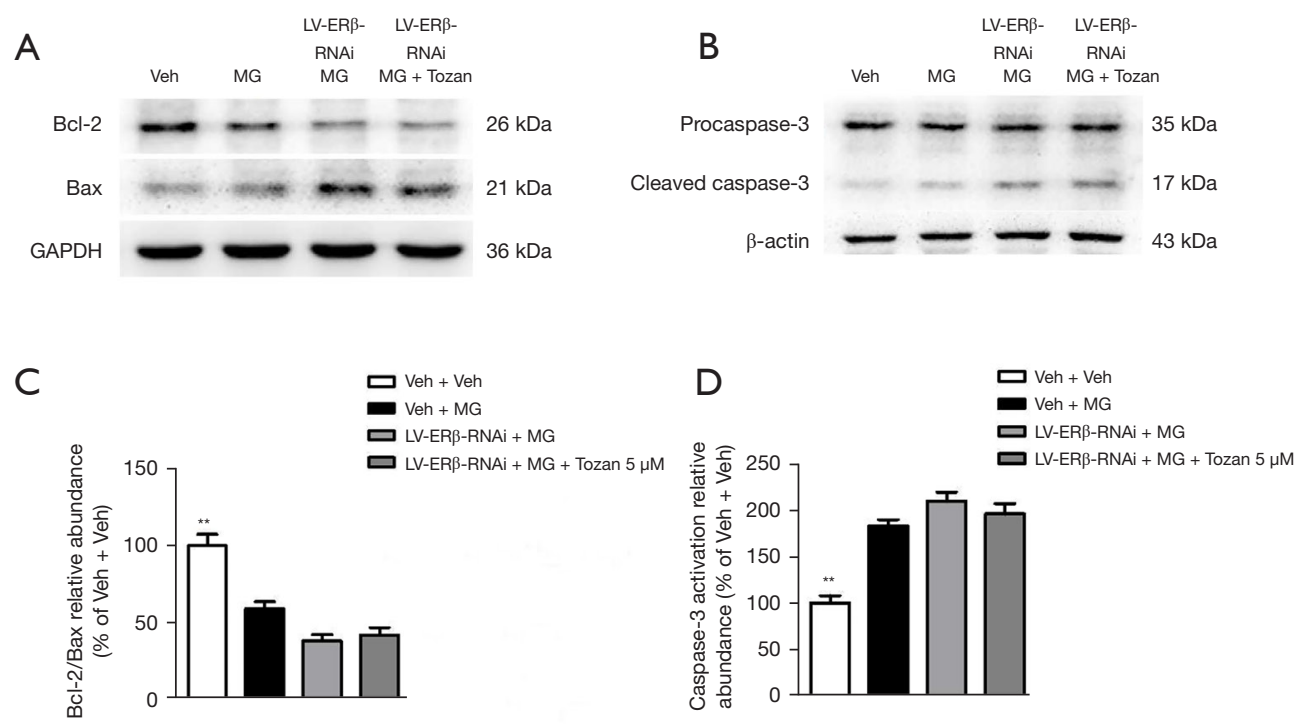

E veh + veh
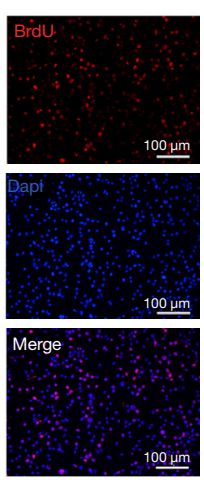

$100 \mu \mathrm{m}$
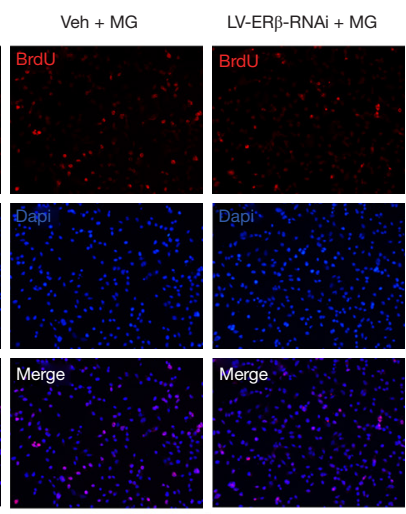

G

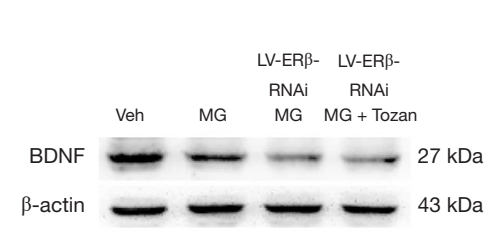

LV-ERB-RNAi $+M G+$ Tozan
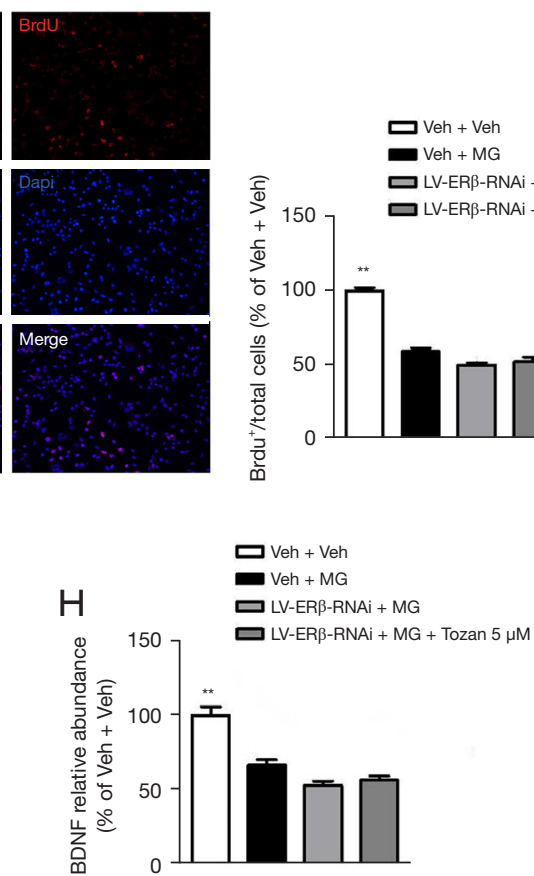

Figure 9 Effects of Tozan on the anti-apoptotic and nerve regeneration effects in the MG-induced ER $\beta$ knockdown SH-SY5Y cells. (A,B) The protein expression of apoptosis-related proteins Bcl-2, Bax, procaspase-3, and cleaved caspase-3 were detected by western blot. (C,D) The quantification of $\mathrm{Bcl}-2 / \mathrm{Bax}$ and cleaved caspase-3/procaspase-3 is shown as the ratio (in percentage) of the Veh + Veh group. Data are shown as means $\pm \operatorname{SEM}(\mathrm{n}=3) .{ }^{* *} \mathrm{P}<0.01 v s$. LV-ER $\beta-R N A i+M G$ group. $(\mathrm{E})$ Effects of Tozan on the number of nascent cells in MG-induced ER $\beta$ knockdown SH-SY5Y cells using Immunofluorescence staining. Representative images of BrdU-labeled nascent cells of all groups. Scale bars $=100 \mu \mathrm{M}$. (F) The results are shown as the ratio of BrdU-labeled cells to DAPI-labeled cells (in percentage) of the Veh + Veh group. Data are shown as means $\pm \mathrm{SEM}(\mathrm{n}=3)$. ${ }^{* *} \mathrm{P}<0.01$ vs. LV-ER $\beta-R N A i+M G$ group. $(\mathrm{G})$ Effects of Tozan on the expression of BDNF protein in the MG-induced ER $\beta$ knockdown SH-SY5Y cells. The protein expression of BDNF in all groups was detected by western blot. (H) Quantitative analysis results of BDNF are shown as the ratio (in percentage) of the Veh + Veh group. Data are shown as means $\pm \operatorname{SEM}(\mathrm{n}=3)$. ${ }^{* *} \mathrm{P}<0.01$ vs. LV-ER $\beta-R N A i+M G$ group. MG, methylglyoxal; ER, estrogen receptor; SEM, standard error of mean. 


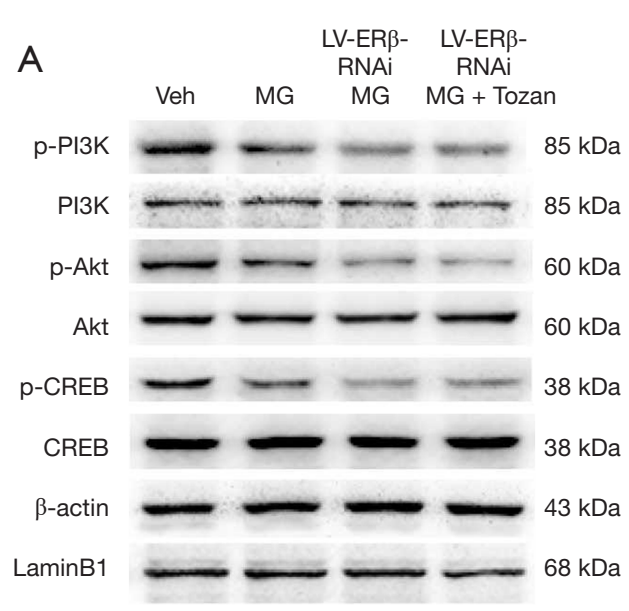

C

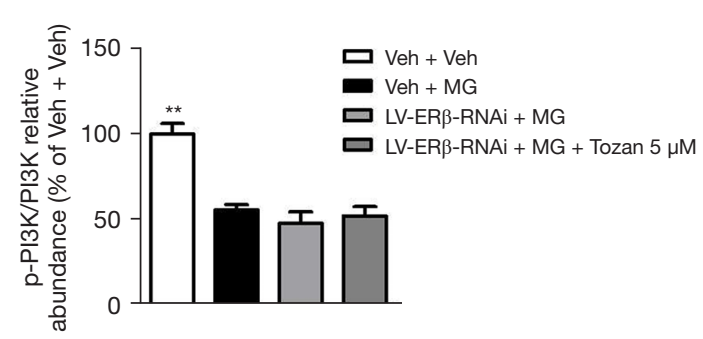

B

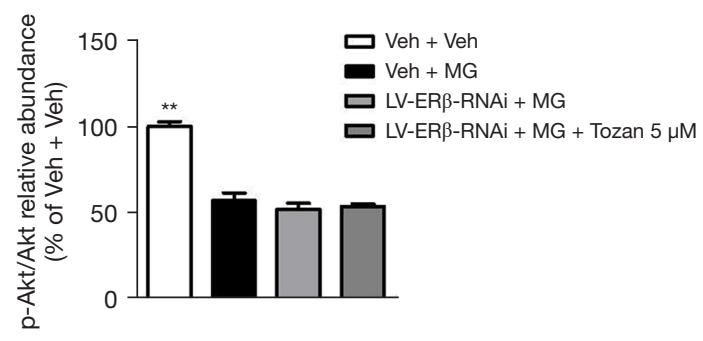

D

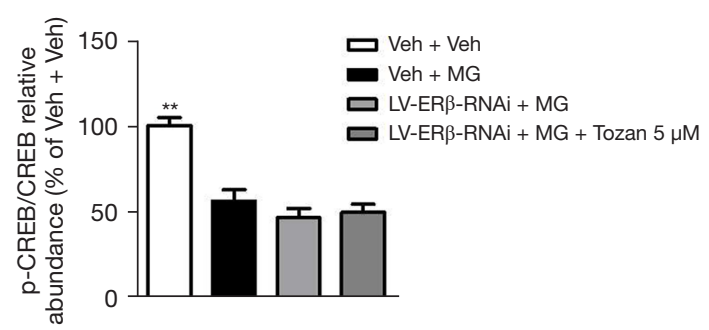

Figure 10 Effects of Tozan on the protein expression of PI3K/Akt-CREB pathway in the MG-induced ER $\beta$ knockdown SH-SY5Y cells. (A) The protein expression of p-PI3K/PI3K, p-Akt/Akt, and p-CREB/CREB in all groups was detected by western blot. (B-D) The quantification of p-PI3K/PI3K, p-Akt/Akt, and p-CREB/CREB is shown as the ratio (in percentage) of the Veh + Veh group. Data are shown as means $\pm \operatorname{SEM}(\mathrm{n}=3) .{ }^{* *} \mathrm{P}<0.01$ vs. $\mathrm{LV}-\mathrm{ER} \beta-\mathrm{RNAi}+\mathrm{MG}$ group. $\mathrm{MG}$, methylglyoxal; ER, estrogen receptor; SEM, standard error of mean.

type 1 diabetic mice. The knockdown of ER $\beta$ in SH-SY5Y cells confirmed that Tozan no longer had these functions.

Recent studies have shown that the occurrence of cognitive impairment in diabetes is closely related to AGEs (17). The accumulation of AGEs promotes oxidative stress by increasing vascular permeability and promotes the production of IGF and interleukin-1. The modification of $\mathrm{A} \beta$ at specific amino acid sites leads to vasculopathy and nerve injury, and is an important cause of diabetic complications (18). Among the active carbonyl compounds, MG is the most likely precursor to AGEs (10). Thus, we chose a MG-induced cell model to study the activity of Tozan against cognitive impairment of T1DM in vitro. The results showed that Tozan had an estrogen-like activity, and the cellular effects of estrogen were mainly mediated by ERs. Tozan ameliorated SH-SY5Y cell injury induced by MG, prevented apoptotic response, and promoted nerve cell regeneration by increasing the protein expression of ER $\beta$ significantly, and did not affect the expression of ER $\alpha$.
Numerous studies showed that diabetes leads to hippocampal dysfunction causing cognitive disorders. Unfortunately, there is no special treatment for cognitive impairment caused by diabetes in humans. Estrogen is a reproductive hormone in vivo, and changes in its concentration during the reproductive cycle, pregnancy, motherhood, and aging process affect the function and shape of the hippocampus in the brain $(19,20)$. It can increase the synaptic density of the hippocampal CA1 region, affect hippocampal synaptic plasticity, and promote the proliferation and differentiation of precursor cells (21). Rodent studies have shown that estrogen therapy can relieve hippocampal neuropathy associated with diabetes (22-25).

Due to the significant side effects of ERT, we synthesized the compound Tozan based on isoflavones, one of the SERMs. However, the mechanisms involved in the cognitive impairment of T1DM are not fully understood. Our previous studies showed that mice that underwent bilateral OVX and were treated with STZ-inducing diabetes 
displayed cognitive impairment in MWM and Y-maze tasks (12). Additionally, the pharmacological activation of $\mathrm{ER} \alpha$ and/or $\mathrm{ER} \beta$ increased the expression of $\mathrm{ER} \alpha$ and $\mathrm{ER} \beta$ in the hippocampus of STZ-induced type 1 diabetic mice and subsequently activated PI3K/Akt, CREB, and BDNF, which suggests that estrogen may play a role through ERs in STZ-induced type 1 diabetic mice (12). Similarly, in this study, we used the estrogen-deficient diabetic mouse model to study the role of Tozan. We found that STZ\&OVX mice showed more serious cognitive impairment in the MWM and Y-maze tests than the control group, but they were improved after the application of Tozan. Notably, Tozan had no significant effect on blood glucose and serum insulin levels of type 1 diabetic mice, which indicates that the effects of Tozan on cognitive impairment in type 1 diabetes mellitus are not achieved through the regulation of blood glucose.

ERs, mainly including ER $\alpha$ and ER $\beta$, are divided into 2 categories: nuclear and membrane receptors. The results showed that Tozan significantly increased the protein expression of cytomembrane ER $\beta$, and weakly up-regulated the expression of cell nucleus ER $\beta$, but had no significant effect on the expression of ER $\alpha$. Thus, it appears that Tozan mainly plays a role in inhibiting apoptosis and promoting nerve regeneration through ER $\beta$. Depending on whether the final result is transcriptional regulation, ER signal transduction can be classified as genomic or nongenomic (26). The genomic mechanism of ER involves gene transcription mediated by nuclear ER activation. The non-genomic ER mechanism is defined as the rapid effect of membrane-related ER interactions leading to the activation of PI3K/Akt signaling pathways (27). The PI3K/ Akt pathway, which is a classical signaling pathway in the human body, is associated with the survival and death of neurons (28). In this signaling pathway, the apoptosisregulating Bcl-2 family, which includes anti-apoptotic proteins (Bcl-2 and $\mathrm{Bcl}-\mathrm{xl}$ ) and pro-apoptotic proteins (Bax), is downstream of Akt (29). The relative ratio of Bcl2/Bax determines whether the neuron lives or dies (30). An increase in this ratio would prevent the activation of Bax, while a decrease in this ratio would induce the homologous oligomerization of Bax in mitochondria, leading to the formation of pore structures in the mitochondrial outer membrane, which would activate the cytochrome c-mediated apoptosis cascade (31).

In addition, due to the possibility of kinase transfer to the nucleus, Akt activation also induces transcriptional activity, which activates transcription factors, such as
CREB (32). CREB is a nuclear transcription factor that regulates the expression of genes involved in neuronal survival and function and plays a role in the formation and retention of learning and memory (33). Its best-known transcriptional target, BDNF, is critical to integrating long-term memory (34), and has been reported to be related to hippocampal-dependent learning (35). The phosphorylation of CREB activates the transcription of pro-survival factors, such as Bcl-2 and BDNF, and the loss of CREB activates the Bax-dependent apoptosis pathway $(15,16)$. In addition, when a ligand-binding nucleus ER activates genomic ER signal transduction, CREB can be directly activated to regulate downstream gene transcription $(36,37)$. The data showed that Tozan mainly activated the PI3K/Akt-CREB signaling pathway through the cell membrane ER $\beta$, a high dose of Tozan $(8 \mathrm{mg} / \mathrm{kg}$ ) activates CREB through the nuclear ER $\beta$, and thus plays a role in resisting apoptosis of the hippocampus and promoting nerve regeneration.

In conclusion, our study confirmed Tozan's roles in ameliorating cognition, neurogenesis, and preventing apoptosis in type 1 diabetes. It may be that these roles are mediated by the activation of the PI3K/Akt-CREB signaling pathway via the cell membrane ER $\beta$ or the CREB via the cell nuclear ER $\beta$. Our observations suggest that Tozan might be a novel, effective, and promising compound for treating memory impairment of type I diabetes mellitus and should provide novel ideas for the further study of estrogen in neurodegenerative diseases and the combined therapy of diabetes.

\section{Acknowledgments}

Funding: This work was supported by grants from the National Natural Science Foundation of China (81603113 and 82071202 to Su-Su Tang, and 81773714 to Hao Hong).

\section{Footnote}

Reporting Checklist: The authors have completed the ARRIVE reporting checklist. Available at https://dx.doi. org/10.21037/atm-21-4439

Data Sharing Statement: Available at https://dx.doi. org/10.21037/atm-21-4439

Conflicts of Interest: All authors have completed the ICMJE uniform disclosure form (available at https://dx.doi. 
org/10.21037/atm-21-4439). Dr. Tang reports grants from the National Natural Science Foundation of China (81603113 and 82071202). Dr. Hong grant from the National Natural Science Foundation of China (81773714). The other authors have no conflicts of interest to declare.

Ethical Statement: The authors are accountable for all aspects of the work in ensuring that questions related to the accuracy or integrity of any part of the work are appropriately investigated and resolved. Experiments were performed under the project license (No.: SYXK2016-0011) granted by the ethics committee of China Pharmaceutical University, in compliance with the guidelines of the National Institutes of Health Guide for the Care and Use of Laboratory Animals.

Open Access Statement: This is an Open Access article distributed in accordance with the Creative Commons Attribution-NonCommercial-NoDerivs 4.0 International License (CC BY-NC-ND 4.0), which permits the noncommercial replication and distribution of the article with the strict proviso that no changes or edits are made and the original work is properly cited (including links to both the formal publication through the relevant DOI and the license). See: https://creativecommons.org/licenses/by-nc-nd/4.0/.

\section{References}

1. Mbanya JC, Sandow J, Landgraf W, et al. Recombinant Human Insulin in Global Diabetes Management - Focus on Clinical Efficacy. Eur Endocrinol 2017;13:21-5.

2. Dorsemans AC, Couret D, Hoarau A, et al. Diabetes, adult neurogenesis and brain remodeling: New insights from rodent and zebrafish models. Neurogenesis (Austin) 2017;4:e1281862.

3. Pasquier F, Boulogne A, Leys D, et al. Diabetes mellitus and dementia. Diabetes Metab 2006;32:403-14.

4. Yaffe K, Blackwell T, Kanaya AM, et al. Diabetes, impaired fasting glucose, and development of cognitive impairment in older women. Neurology 2004;63:658-63.

5. Viña J, Lloret A. Why women have more Alzheimer's disease than men: gender and mitochondrial toxicity of amyloid-beta peptide. J Alzheimers Dis 2010;20 Suppl 2:S527-33.

6. Siddiqui AN, Siddiqui N, Khan RA, et al. Neuroprotective Role of Steroidal Sex Hormones: An Overview. CNS Neurosci Ther 2016;22:342-50.

7. Collaborative Group On Epidemiological Studies Of
Ovarian Cancer; Beral V, Gaitskell K, et al. Menopausal hormone use and ovarian cancer risk: individual participant meta-analysis of 52 epidemiological studies. Lancet 2015;385:1835-42.

8. Gilbert ER, Liu D. Anti-diabetic functions of soy isoflavone genistein: mechanisms underlying its effects on pancreatic $\beta$-cell function. Food Funct 2013;4:200-12.

9. Soni M, Rahardjo TB, Soekardi R, et al. Phytoestrogens and cognitive function: a review. Maturitas 2014;77:209-20.

10. Yoon KD, Yamamoto K, Ueda K, et al. A novel source of methylglyoxal and glyoxal in retina: implications for agerelated macular degeneration. PLoS One 2012;7:e41309.

11. Lenzen $S$. The mechanisms of alloxan- and streptozotocininduced diabetes. Diabetologia 2008;51:216-26.

12. Tang SS, Ren Y, Xu LJ, et al. Activation of ER $\alpha$ and/ or ER $\beta$ ameliorates cognitive impairment and apoptosis in streptozotocin-induced diabetic mice. Horm Behav 2018;105:95-103.

13. Tang SS, Ren $Y$, Ren XQ, et al. ER $\alpha$ and/or ER $\beta$ activation ameliorates cognitive impairment, neurogenesis and apoptosis in type 2 diabetes mellitus mice. Exp Neurol 2019;311:33-43.

14. Cominski TP, Turchin CE, Hsu MS, et al. Loss of the mu opioid receptor on different genetic backgrounds leads to increased bromodeoxyuridine labeling in the dentate gyrus only after repeated injection. Neuroscience 2012;206:49-59.

15. Zhang L, Zhao H, Zhang X, et al. Nobiletin protects against cerebral ischemia via activating the p-Akt, p-CREB, BDNF and Bcl-2 pathway and ameliorating BBB permeability in rat. Brain Res Bull 2013;96:45-53.

16. Lonze BE, Riccio A, Cohen S, et al. Apoptosis, axonal growth defects, and degeneration of peripheral neurons in mice lacking CREB. Neuron 2002;34:371-85.

17. Stirban A, Gawlowski T, Roden M. Vascular effects of advanced glycation endproducts: Clinical effects and molecular mechanisms. Mol Metab 2014;3:94-108.

18. van Eupen MG, Schram MT, Colhoun HM, et al. The methylglyoxal-derived AGE tetrahydropyrimidine is increased in plasma of individuals with type 1 diabetes mellitus and in atherosclerotic lesions and is associated with sVCAM-1. Diabetologia 2013;56:1845-55.

19. Daniel JM. Estrogens, estrogen receptors, and female cognitive aging: the impact of timing. Horm Behav 2013;63:231-7.

20. Pawluski JL, Brummelte S, Barha CK, et al. Effects of steroid hormones on neurogenesis in the hippocampus 
of the adult female rodent during the estrous cycle, pregnancy, lactation and aging. Front Neuroendocrinol 2009;30:343-57.

21. Ormerod BK, Lee TT, Galea LA. Estradiol initially enhances but subsequently suppresses (via adrenal steroids) granule cell proliferation in the dentate gyrus of adult female rats. J Neurobiol 2003;55:247-60.

22. Garris DR. Estrogenic stimulation of hypothalamic-limbic system metabolism in ageing diabetic C57BL/KsJ mice. Neuroendocrinology 1999;69:424-9.

23. Lannert H, Wirtz P, Schuhmann V, et al. Effects of Estradiol (-17beta) on learning, memory and cerebral energy metabolism in male rats after intracerebroventricular administration of streptozotocin. J Neural Transm (Vienna) 1998;105:1045-63.

24. De Nicola AF, Saravia FE, Beauquis J, et al. Estrogens and neuroendocrine hypothalamic-pituitary-adrenal axis function. Front Horm Res 2006;35:157-68.

25. Toung TK, Hurn PD, Traystman RJ, et al. Estrogen decreases infarct size after temporary focal ischemia in a genetic model of type 1 diabetes mellitus. Stroke 2000;31:2701-6.

26. Björnström L, Sjöberg M. Mechanisms of estrogen receptor signaling: convergence of genomic and nongenomic actions on target genes. Mol Endocrinol 2005;19:833-42.

27. Marino M, Galluzzo P, Ascenzi P. Estrogen signaling multiple pathways to impact gene transcription. Curr Genomics 2006;7:497-508.

28. Peltier J, O'Neill A, Schaffer DV. PI3K/Akt and CREB regulate adult neural hippocampal progenitor proliferation and differentiation. Dev Neurobiol 2007;67:1348-61.

29. Parcellier A, Tintignac LA, Zhuravleva E, et al. PKB and the mitochondria: AKTing on apoptosis. Cell Signal

Cite this article as: Tang SS, Xing SY, Zhang XJ, Ren XQ, Hong H, Long Y. Neuroprotective effects of novel compound Tozan on cognition, neurogenesis and apoptosis in diabetes. Ann Transl Med 2021;9(18):1471. doi: 10.21037/atm-21-4439
2008;20:21-30.

30. Cheng CY, Tang NY, Kao ST, et al. Ferulic Acid Administered at Various Time Points Protects against Cerebral Infarction by Activating p38 MAPK/p90RSK/ CREB/Bcl-2 Anti-Apoptotic Signaling in the Subacute Phase of Cerebral Ischemia-Reperfusion Injury in Rats. PLoS One 2016;11:e0155748.

31. Zhu L, Hao J, Cheng M, et al. Hyperglycemia-induced Bcl-2/Bax-mediated apoptosis of Schwann cells via mTORC1/S6K1 inhibition in diabetic peripheral neuropathy. Exp Cell Res 2018;367:186-95.

32. Hetman M, Gozdz A. Role of extracellular signal regulated kinases 1 and 2 in neuronal survival. Eur J Biochem 2004;271:2050-5.

33. Saura CA, Cardinaux JR. Emerging Roles of CREBRegulated Transcription Coactivators in Brain Physiology and Pathology. Trends Neurosci 2017;40:720-33.

34. Cunha C, Brambilla R, Thomas KL. A simple role for BDNF in learning and memory? Front Mol Neurosci 2010;3:1.

35. Tyler WJ, Alonso M, Bramham CR, et al. From acquisition to consolidation: on the role of brain-derived neurotrophic factor signaling in hippocampal-dependent learning. Learn Mem 2002;9:224-37.

36. Bourque M, Dluzen DE, Di Paolo T. Signaling pathways mediating the neuroprotective effects of sex steroids and SERMs in Parkinson's disease. Front Neuroendocrinol 2012;33:169-78.

37. Correia SC, Santos RX, Cardoso S, et al. Effects of estrogen in the brain: is it a neuroprotective agent in Alzheimer's disease? Curr Aging Sci 2010;3:113-26.

(English Language Editor: L. Huleatt) 